\title{
ESSAYS
}

\section{TALKING "CULTURE": GENDER, RACE, NATION, AND THE POLITICS OF MULTICULTURALISM}

\section{Leti Volpp*}

\author{
The risks of talking culture are immense. ${ }^{1}$
}

\section{INTRODUCTION}

The recent publication of an article by Doriane Lambelet Coleman, "Individualizing Justice Through Multiculturalism: The Liberals' Dilemma," in the Columbia Law Review, raises significant questions concerning legal scholarship on the subjects of culture, gender, race, and multiculturalism. Legal academia has not been immune to what Keith Aoki describes as "the seductive but pernicious lure of 'backlash' politics"- the "vituperative (and largely unconscious) reaction to the social progress wrought by feminists, people and communities of color, and gay men and lesbians at virtually every level of American life"3 - which has appeared in legal journals in the form of backlash scholarship. ${ }^{4}$

* B.A. Princeton University, 1986; M.S.P.H. Harvard School of Public Health, 1988; M.Sc. University of Edinburgh, 1989; J.D. Columbia Law School, 1993. Heartfelt thanks to the following people for their encouragement, advice and support: Keith Aoki, Farah Brelvi, Robert Chang, Diane Chin, Kimberlé Crenshaw, Brent Edwards, David Eng, Richard Ford, Neil Gotanda, Inderpal Grewal, Isabelle Gunning, Lucas Guttentag, Deeana Jang, Hyun Sook Kim, Cynthia Lee, Jayne Lee, Lisa Lowe, Holly Maguigan, Madhavi Sunder, Kendall Thomas, Sophie Volpp, Patricia Williams, Josephine Yeh, and Janet YeskEffroy. I also would like to thank Wendy Hickok Robinson and Bill Savitt of the Columbia Law Review.

1. Sherene Razack, What Is to Be Gained by Looking White People in the Eye? Culture, Race, and Gender in Cases of Sexual Violence, 19 Sigus 894, 918 (1994).

2. Doriane Lambelet Coleman, Individualizing Justice Through Multiculturalism: The Liberals' Dilemma, 96 Colum. L. Rev. 1093 (1996).

3. Keith Aoki, The Politics of Backlash and the Scholarship of Reconstruction, 81 Iowa L. Rev. (forthcoming 1996) (manuscript at 5, 1-2, on file with the Columbia Law Review) (citing Susan Faludi, Backlash: The Undeclared War Against American Women (1991)).

4. For examples of backlash scholarship in legal journals, see Jim Chen, Unloving, 80 Iowa L. Rev. 145 (1994) (deploring "racial fundamentalism" of Asian American legal scholarship); Daniel A. Farber \& Suzanna Sherry, Is the Radical Critique of Merit AntiSemitic? 83 Cal. L. Rev. 853 (1995) (arguing critiques of merit to be anti-Semitic); Daniel A. Farber \& Suzanna Sherry, Telling Stories Out of School: An Essay on Legal Narratives, 45 Stan. L. Rev. 807 (1993) (critiquing narrative as inferior form of legal scholarship). For other examples of backlash scholarship, see Richard Bernstein, Dictatorship of Virtue: Multiculturalism and the Battle for America's Future (1994) (critiquing "multiculturalist movement"); Allan Bloom, The Closing of the American Mind: How Higher Education Has Failed Democracy and Impoverished the Souls of Today's Students (1987) (claiming universities destroyed by demands of students, feminism, and multiculturalism); Dinesh 
Backlash scholarship attempts to preempt debate on the difficult questions raised by such subjects as multiculturalism and race. This attempt follows four strategies. First, backlash scholarship denies that scholarship such as critical race theory exists. ${ }^{5}$ Second, it asserts that such scholarship is invalid as scholarship qua scholarship-for example, by laying claims to legitimacy as "objective" and "neutral" scholarship, while critiquing other scholarship as "subjective." Third, backlash scholarship redefines or appropriates key imagery, terms, and tropes that are distorted and redeployed in the service of what has been named "color-blind meritocratic fundamentalism."7 Lastly, it tends to misrepresent previous literature that is the subject of attack. ${ }^{8}$

Coleman self-identifies as "liberal" and "progressive." $\mathrm{Her}$ article nonetheless falls within the genre of backlash, with its mode of scholarship, its rejection of race consciousness, and its support for United States ethnocentrism. In fact, Coleman's article exemplifies two variants of backlash scholarship. One, in the name of "liberalism," laments that multiculturalism goes too far in threatening our "unified culture." 10 The

D'Souza, The End of Racism: Principles for a Multicultural Society (1995) (critiquing civil rights movement and multiculturalism); Dinesh D'Souza, Illiberal Education: The Politics of Race and Sex on Campus (1991) (criticizing "victim's revolution" on college campuses); Elizabeth Fox-Genovese, "Feminism Is Not the Story of My Life": How Today's Feminist Elite Has Lost Touch with the Real Concerns of Women (1996) (calling feminism elitist and out of touch with "real women"); William A. Henry III, In Defense of Elitism (1994) (defending elitism and notion of meritocracy); Katie Roiphe, The Morning After: Sex, Fear, and Feminism on Campus (1993) (charging "date-rape hysteria" on college campuses to be result of feminist exaggeration).

5. See, e.g., Christopher A. Ford, Administering Identity: The Determination of "Race" in Race-Conscious Law, 82 Cal. L. Rev. 1231 (1994) (analyzing legal articulations of race-consciousness without mentioning any scholar associated with Critical Race Theory); see also Aoki, supra note 3 (manuscript at 6 ).

6. See Aoki, supra note 3 (manuscript at 6); Jerome M. Culp, Jr., Posner on Duncan Kennedy and Racial Difference: White Authority in the Legal Academy, 41 Duke L.J. 1095, 1097 (1992) (critiquing Judge Richard Posner for suggesting that legal scholarship by blacks is inadequate according to "objective standards," and for assuming that only black and not white scholars write from a subjective perspective).

7. Aoki, supra note 3 (manuscript at 6-7) (quoting Duncan Kennedy, A Cultural Pluralist Case for Affirmative Action in Legal Academia, 1990 Duke L.J. 705). For an example of such a distortion, see, e.g., Dinesh D'Souza, The End of Racism, supra note 4, at 67-114 (asserting that slavery in the United States was not racist).

8. See, e.g., Garrett Epps, What's Loving Got to Do with It?, 81 Iowa L. Rev. (forthcoming 1996) (manuscript at 3-4, on file with the Columbia Law Review) (criticizing Jim Chen's argument as attacking a thesis not mentioned or defended and cbaracterizing such argument as "rhetorical assault hiding behind a pseudo-scholarly disguise").

9. See Coleman, supra note 2, at 1095 n.8:

The words "progressive" and "liberal" are used interchangeably throughout this Article. They are used in the very best sense of the New Deal democratic tradition. In doing so, I reject the pejorative cast that conservatives recently have tried to give to the words, and to adherents, including myself, of their underlying political philosophies.

10. See, e.g., the work of liberal Arthur Schlesinger, who warns of an "ethnic upsurge," and "unprecedented . . protest against the Anglocentric culture" that 
other yokes cultural feminism to victims' rights, and charges that multiculturalism threatens "women's progress." 11 In pursuing these agendas, Coleman's thesis relies on a regressive vision of immigrant communities, of multiculturalism, and of scholarship on these issues. As a result, her article fails to adequately address the complex questions raised by the emergence of "cultural defenses."

Coleman's argument can be summarized as follows. Non-European immigrants, particularly those from Asia and Africa, bring patriarchal customs with them to the United States, such as parent-child suicide, wife beating and killing, marriage by capture, and female genital mutilation. As demonstrated by these "practices," the cultural space inhabited by non-European immigrants is comparable "to a place European-American women began leaving in the mid-to-late nineteenth century." 12 In deference to the notion of multiculturalism, however, some courts have allowed consideration of cultural evidence in cases involving immigrant defendants. Allowing consideration of this evidence results in the "liberals' dilemma": an inherent tension that is created between the values of feminism and multiculturalism. This dilemma must be solved by barring cultural evidence, because admitting cultural evidence discriminates against the victims of immigrant defendants, violating the anti-discrimination principle of the Equal Protection Clause. Applying a balancing test yields the conclusion that the interests of immigrant victims should trump the interests of immigrant defendants. Further, allowing culture in the courtroom risks "balkanization" and the recreation of "gender or racial apartheid." 13 Nothing, including multiculturalism, can be permitted to "pervade the law." 14

This Essay responds to Coleman's position on the "cultural defense." It places her thesis within a broader scholarly context in order to clarify her article's unstated theoretical underpinnings. In addition, it makes explicit the premises, inconsistencies and ellipses on which her argument relies. Part I discusses her position as emerging from a particular strain of feminism which has been problematized both as gender essentialist and as endorsing "victims' rights." This section reveals her argument's reliance on a problematic deployment of female genital surgeries and a misleading analogy between parent-child suicide cases and the Susan

"threatens the original theory of America as 'one people,' a common culture, a single nation." Arthur M. Schlesinger Jr., The Disuniting of America 17 (1991).

For a discussion of why backlash from the mouths of liberals-supposed allies-is particularly pernicious, see Richard Delgado, The Rodrigo Chronicles: Conversations About America and Race (1995).

11. See, e.g., Cathy Young, Feminists' Multicultural Dilemma, Chi. Trib., July 8, 1992, at 15. Young, whose work Coleman uses to support her argument, asserts that multiculturalists seek to destroy Western civilization, which is the "only civilization" that has sought to empower women.

12. Coleman, supra note 2 , at 1140.

13. Id. at 1161-62.

I4. Id. at 1100 . 
Smith case. It also shows that Coleman's conclusion that feminism and multiculturalism are antithetical derives from her failure to use an intersectional analysis. Part II addresses Coleman's limited presentation of culture as bound by certain anthropological constructions such as "rituals," "customs," "practices" and "traditions." This section explicates the manner in which such notions of culture fail to consider the role of external factors in affecting a community's culture, and deny that culture can be contested within communities. Part III discusses the way in which Coleman's adherence to "neutral principles" and her proinotion of "cultureblindness" are linked to the ideology of "colorblindness," and can yield detrimental results for women of color. Part IV examines the depiction of non-European immigrant culture as primitive and incompatible with so-called "American" values and places it within the context of scholarship on cultural racism and multiculturalism. Lastly, Part V discusses what Coleman's prescription for reform would mean in the courtroom, briefly examines another area of law which is raising similar questions, and suggests some guidelines for future considerations of culture and law.

\section{THE OtHER WOMAN}

Coleman's position on "cultural defenses" is premised on the notion that non-European immigrant women are subsumed in patriarchal culture. She depicts feminism as "Euro-American," and non-European culture as defined by men, resorting to a single axis framework critiqued in the scholarship on intersectionality. This bifurcation of race and gender leads to the mistaken conclusion that the goals of multiculturalism and feminism are antithetical. In addition, the article erroneously characterizes parent-child suicide cases in order to support the conclusion that the rights of victims must always trump those of defendants in this area of law. This mischaracterization stems from a reliance upon the ideology of victims' rights, and from a failure to examine the subject position of nonEuropean immigrant women.

Coleman asserts that when non-European immigrant women come to the United States, they enter a society that "is a better place for women from the Western perspective." 15 She warns that the "patriarchal values brought to our country by some immigrants serve as a barrier to the advancement of women from these cultures."16 Accepting non-European "cultural norms" "takes two steps back," 17 and forces immigrant women "to go back to a time when American law formally discriminated against women and people of color, a time to which most would agree we as a society do not want to return." 18

18. Id. 
Such a perspective assumes that women immigrating to the United States are moving into a more liberated, enlightened, and emancipated society than the one from which they have come. It does not conceive the culture of immigrants from Africa or Asia to be anything but patriarchal in certain contexts, and believes that United States women, who live free from the constraints of non-European culture, are more liberated than their oppressed counterparts. The result of Coleman's position is to describe non-European immigrant culture as "male," and feminism as "American." African and Asian culture are exclusively patriarchal, and defined only by men, while feminists are always "Western" or "American" women. These assumptions lead Coleman to ignore two key points which have long been discussed within feminist scholarship: "Western" or "American" culture is also patriarchal, and non-European immigrant women are also feminists.

Coleman's article presents a version of feminism which replicates the colonialist ${ }^{19}$ feminism of a century ago, ${ }^{20}$ which has been critiqued as imperialist $^{21}$ and racist. ${ }^{22}$ As Hazel Carby has described, the "feminist" version of racist ideology presents immigrant women as requiring liberation into the "progressive" social mores and customs of the metropolitan West: ${ }^{23}$

19. The term "colonialism" refers to "the process by which the European powers reached positions of economic, military, political, and cultural hegemony in much of Asia, Africa, and the Americas. Colonialism took the form both of distant control of resources ... and of direct European settlement." Ella Shohat \& Robert Stam, Unthinking Eurocentrism: Multiculturalism and the Media 15 (1994).

20. As Vron Ware describes British feminism of the late 19th century:

For many women, the geographical extent of the Empire ... immediately created the possibility of totally unequal and dependent relationships in which women from the "Mother Country" helped to define and describe the conditions under which the colonized women lived, as well as the nature of those women themselves .... [T] he grotesque imagery of the suffering Indian female, halfway between dog and saint ... ha[s] been instrumental in reinforcing the image of "Oriental" or "Eastern" women as passive, quiescent victims of male power, whose subordination was sometimes connected with, but always relative to, that of Western women .... Feminism could thus be seen as part of the civilizing process, along with English civil law, education and Christianity.

Vron Ware, Beyond the Pale: White Women, Racism and History 163 (1992).

21. The term "imperialism" refers to a specific form of colonialism, whereby conquest of territory became linked to two main factors: the systematic search for markets and exportation of capital, and First World intervention in Third World nations, post independence. See Shohat \& Stam, supra note 19, at 15; see also Cultures of United States Imperialism (Amy Kaplan \& Donald E. Pease, eds., 1993) (collection of essays examining imperialism as both an internal process of cultural appropriation and as an external struggle over international power).

22. For critiques of certain versions of feminism as racist, see Maria Mies et al., Women: The Last Colony (1988); Trinh T. Minh-ha, Woman, Native, Other: Writing Postcoloniality and Feminism (1989); Gayatri C. Spivak, In Other Worlds: Essays in Cultural Politics (Routledge 1988) (1987); Vron Ware, supra note 20.

23. The use of liberation narratives is not limited to the context of gender. For a critique of liberation narratives depicting Third World gays and lesbians in need of 
The actual struggles that Asian [immigrant] women are involved in are ignored in favour of applying theories from the point of view of a more "advanced," more "progressive" outside observer .... When barbarous sexual practices are to be described the "Third World" is placed on display and compared to the "First World" which is seen as more "enlightened" or "progressive."24 Such essentialized images of the "Third World woman" are predicated upon assumptions about Western women as secular, liberated, and having control over their own lives-but these assumptions are not grounded in material reality. Rather, as Chandra Mohanty writes, Western women's liberation is a product of discursive self-representation, which contrasts Western women's enlightenment with the suffering of the "Third World woman."25

Given this history of imperialist feminism, it is fascinating that Coleman includes female genital surgeries ("FGS") ${ }^{26}$ in her list of four "cases that best illustrate the use of cultural evidence as a defense to criminal conduct,"27 especially when she does not describe or cite a single case involving FGS where cultural evidence has been presented. There is no indication that any kind of "cultural defense" was presented in the case she uses to describe "the time honored tradition of female circumcision." ${ }^{28}$ Nonetheless, she suggestively writes, "[t]he State charges the woman with child abuse, but is unable to convict her," ${ }^{29}$ leaving the implication of a successful "cultural defense." 30 That Coleman includes FGS in

Western salvation, see JeeYeun Lee, Towards a Queer Korean American Diasporic History, in Q \& A: Queer in Asian America [working title] (David Eng \& Alice Hom, eds. forthcoming 1997) (manuscript at 16, on file with the Columbia Law Review) ("People in Asia, the Third World, or racial minority communities are not more homophobic, they are differently homophobic, in ways conditioned not only by beliefs, values, and circumstances, but also by histories of western [sic] imperialism and U.S. racism."); see also Carmen Vazquez, Bursting the Lavender Bubble, 4 Out/Look 53, 54 (1991) ("Challenging homophobia in the Latino community is no more and no less a challenge than it is to cballenge it in any other ethnic community.").

24. Hazel V. Carby, White Woman Listen! Black Feminism and the Boundaries of Sisterhood, in The Empire Strikes Back: Race and Racism in 70s Britain 212, 216 (CCCS eds., 1982).

25. Mohanty suggests that if Western women's empowerment were, in fact, a material reality, there would be no need for feminist movements in the West. See Chandra $T$. Mohanty, Under Western Eyes: Feminist Scholarship and Colonial Discourses, in Third World Women and the Politics of Feminism 51, 74 (Chandra T. Mohanty et al. eds., 1991).

26. Isabelle Gunning suggests using the term "female genital surgeries" rather than "genital mutilation," which immediately projects a negative moral assessment, or "female circumcision," which implies a mild operation equivalent to male circumcision. Isabelle $\mathbf{R}$. Gunning, Arrogant Perception, World-Travelling and Multicultural Feminism: The Case of Female Genital Surgeries, 23 Colum. Hum. Rts. L. Rev. 189, 193 n.15 (1992).

27. Coleman, supra note 2, at 1099.

28. Id. at 1094.

29. Id.

30. See Jane Hansen \& Deborah Scroggins, Female Circumcision: U.S., Georgia Forced to Face Medical, Legal Issues, Atlanta J. \& Const., Nov. 15, 1992, at A1. As Coleman points out later in her article, the prosecution was unsuccessful because the prosecutor was 
her article can be explained by the fact that FGS is used to exemplify barbaric Third World practices within the discourse of North American feminism. ${ }^{31}$ Western discourse on FGS directs a "horrified gaze" towards its colonial and post-colonial subjects, rather than looking at the complexities surrounding the issue of FGS. ${ }^{32}$ Coleman's depiction of FGS betrays no knowledge of the tremendous controversy that has surrounded Western feminist depiction of FGS as a cause célebre, nor of the thoughtful interventions that have suggested tactics for achieving a dialogue on the issue between feminists in Africa and the West. ${ }^{33}$ Such an erasure of history and scholarship eviscerates the possibility for meaningful discussion on the issue.

Coleman's article invokes the name of women's progress in order to legitimize the exclusion of non-European immigrant culture from consideration by the law. In making this argument, Coleman allies herself with Heritage Foundation lecturer Cathy Young. ${ }^{34}$ Young asserts that "radical

unable to prove who was actually responsible for the FGS. See Coleman, supra note 2, at 1113.

31. See, e.g., Mary Daly, Gyn/Ecology: The Metaethics of Radical Feminism 153-77 (1978); Fran P. Hosken, The Hosken Report: Genital and Sexual Mutilation of Females (4th ed. 1994); Hanny Lightfoot-Klein, Prisoners of Ritual: An Odyssey into Female Genital Circumcision in Africa 38-46 (1989); Fran P. Hosken, Female Genital Mutilation and Human Rights, 1 Feminist Issues, Summer 1981, at 3, 8-9; Fran P. Hosken, Genital Mutilation, 12 Science for the People, Nov./Dec. 1980, at 12, 15; Robin Morgan and Gloria Steinem, The International Crime of Genital Mutilation, Ms., March 1980, at 65.

32. These complexities might include the way that poor women face limited health care and educational opportunities, and suffer from the denial of economic and political agency due to global inequalities, rearticulations of patriarchies in specific regions, and the legacies of colonization. See Inderpal Grewal and Caren Kaplan, Warrior Marks: NeoColonial Discourse and Global Feminism's "Lesbian" Body 3 (unpublished manuscript, on file with the Columbia Law Review).

33. See, e.g., Carby, supra note 24, at 216; Gunning, supra note 26, at 197-205; Isabelle R. Gunning, Female Genital Surgeries and Multicultural Feminism: The Ties That Bind, the Differences that Distance, 1994 Third World Legal Stud. 17, 17-19; Isabelle R. Gunning, Female Genital Surgeries in Imperial Culture: Feminist Discourses as Reductive Discourses-Some Legal Implications, in Multicultural Feminism (Ella Shohat, ed. forthcoming) (manuscript at 8,19 , on file with the Columbia Law Review); Hope Lewis, Between Irua and "Female Genital Mutilation": Feminist Human Rights Discourse and the Cultural Divide, 8 Harv. Hum. Rts. J. 1, 48-49 (1995); Kagendo Murungi, “Get Away from My Genitals": A Commentary on Warrior Marks, 2 Interstices 11, 11-15 (1994); Bronwyn Winter, Women, the Law, and Cultural Relativism in France: The Case of Excision, in Rethinking the Political: Gender, Resistance, and the State 315, 315-17 (Barbara Laslett et al. eds., 1995).

Gunning's proposed methodology, for example, suggests that Western feminists pondering FGS avoid "arrogant perception" and identify interconnectedness through "world-travelling." World-travelling means that a woman should: 1) look to her own historical context; 2) see herself as the other woman might perceive her; and 3) see the other woman, her world, and her sense of self through her eyes. See Gunning, supra note 26 , at $197-205$.

34. See Young, supra note 11, at 15. Susan Faludi identifies Young, along with Katie Roiphe, Christina Hoff Sommers, Rene Denfeld, Karen Lehrman, and Elizabeth FoxGenovese, as a group of "pseudofeminists" supported by the media, whose "dismissive-to- 
multiculturalists" seek to "promote the idea that every culture should be judged on its own terms," which puts feminists "in a painfully awkward position." 35 Both Coleman and Young believe that "cultural defenses" force a choice between multiculturalism and women's progress, and that multiculturalism must yield. ${ }^{36}$ Such a privileging of women's rights over culture results in an embrace of gender consciousness and rejection of race consciousness. These contradictory impulses rely on the misperception that supporting the rights of women requires abandoning any consideration of race or culture, ${ }^{37}$ because non-Western culture is somehow more "chauvinistic" than "United States culture."

By positioning feminism as "Euro-American" and non-European culture as defined only by men, Coleman's thesis resorts to a single axis framework, frequently critiqued in the scholarship on intersectionality. ${ }^{38}$ A parallel move is the implicit racing of women as "white," and thinking of "blacks" or "Asians" or any other racially or ethnically defined category as "male." This essentialism erases the intersection inhabited by people subjected to multiple oppressions, which has been described for black women as "a political vacuum of erasure and contradiction maintained by

outright-hostile attitudes . . . locate them firmly on the antifeminist side of the ledger." Susan Faludi, "I'm Not a Feminist But I Play One on TV," Ms., Mar./Apr. 1995, at 31, 32, 39.

35. Young, supra note 11 , at 15 . Young writes:

As Islamic fundamentalists remind us, equality of the sexes is a Western value judgment. Moreover, it is a standard by which most non-Western cultures-even if you allow for a few quasi-matriarchal tribes-come up short . . . . The United States embraces millions of immigrants from a diverse mix of cultures. According to the "politically correct" gospel . . . these immigrants and their children should be encouraged to preserve their own cultural mores and identities; assimilation is viewed as a form of psychic violence. Yet in many cases, these values include the extreme subjugation of women. What's a feminist to do?

Id.

36. See id.:

The politically correct, for all their noble claims are not concerned about women's rights or human rights. Their real purpose is to denigrate and tear down Western civilization. We who cherish Western values must affirm the ideal of equal opportunity and individual rights-regardless of sex or race-as the fulfillinent of the best in Western and American tradition. The real believer in racial and sexual equality will work to make sure that the Western heritage belongs to everyone.

See also Coleman, supra note 2 , at 1166 .

37. See Coleman, supra note 2 , at 1098 ("I believe that there are several reasons for choosing rights over culture.").

38. For examples of works that critique the use of a single axis framework for failing to address the experiences of those who live at the intersection of interlocking forms of oppression, see sources cited infra note 44 .

Coleman does acknowledge that the argument for using an intersectional analysis can be considered "compelling," although her article does not follow this methodology. See Coleman, supra note 2, at 1096 n.16 ("Volpp makes the compelling argument that women of color, and perhaps particularly immigrant women of color, are uniquely situated at the intersection of race, ethnicity, national origin, and gender, and thus that this dilemma appears to be more poignant for these women."). 
the almost routine polarization of 'blacks and women' into separate and competing political camps." 39

Intersectionality is not about alternatively identifying as a member of one group or another, but is about critiquing discourses-political, structural, representational - that are shaped to respond to exclusive and separable categories. ${ }^{40}$ Because intersectionality can be misread to freeze identity along a limited number of axes, it may be helpful to use instead the construct of subject positions, so that subjecthood is understood not as unitary and constructed by totalizing, modernist discourse, but as multiple and fragmented. Our positionalities-as gendered subject, as class subject, as racial subject-can be understood as the result of various social relations formed through different discourses and our own reappropriations of tradition. ${ }^{41}$

The use of a single axis framework-looking at gender unmediated by any other social forces, such as race, immigrant status, poverty, sexuality, or imperialism-facilitates the assumption that the United States is the premier site of liberation for immigrant women, as well as the claim that immigrant "culture" is determined by misogynistic men. This practice allows the erasure of resistant experiences and the very agency of immigrant women-whether they are found in these cases as legallydefined victims, or as defendants. 42

Coleman's article's brand of feminism is also predicated on the notion of a unitary female subject. Cultural feminists developed the modern construct, "woman," by privileging sex differences over any other basis of oppression and asserting the existence of universal gender

39. Kimberle Crenshaw, Whose Story Is It, Anyway? Feminist and Antiracist Appropriations of Anita Hill, in Race-ing Justice, En-gendering Power: Essays on Anita Hill, Clarence Thomas, and the Construction of Social Reality 402, 403 (Toni Morrison ed., 1992).

40. Cf. Houston A. Baker, Jr.'s critique of intersectionality in 'You Cain't Trus' It: Experts Witnessing in the Case of Rap, in Black Popular Culture 132, 135 (Gina Dent ed., 1992) (reducing intersectional analysis to "whether she should judge 2-Live Crew as a black or as a woman").

41. See Spivak, supra note 22, at 244-47; Robert S. Chang, The End of Innocence or Politics After the Fall of the Essential Subject, 45 Am. U. L. Rev. 687, 690-91 (1996); Donna Haraway, A Manifesto for Cyborgs: Science, Technology, and Socialist Feminism in the 1980s, in Feminism/Postmodernism 190 (Linda J. Nicholson ed., 1990); Chantal Mouffe, Hegemony and New Political Subjects: Toward a New Concept of Democracy, in Marxism and the Interpretation of Culture 89, 89-90 (Cary Nelson \& Lawrence Grossberg eds., Stanley Gray trans., 1988); Carl F. Stychin, Identities, Sexualities, and the Postmodern Subject: An Analysis of Artistic Funding hy the National Endowment for the Arts, 12 Cardozo Arts \& Ent. L.J. 79 (1994).

42. On resistance and agency of "Third World women" and women of color, see generally Kumari Jayawardena, Feminism and Nationalism in the Third World (1988); Making Face, Making Soul: Haciendo Caras (Gloria Anzaldua ed., 1990); This Bridge Called My Back (Cherrie Moraga \& Gloria Anzaldúa eds., 1983); Mohanty, supra note 25. 
subordination across time and space. ${ }^{43}$ This version of feminism has been criticized as gender essentialism. ${ }^{44}$. As Inderpal Grewal points out, sexual violence, namely domestic violence and rape, has become the primary agenda of United States cultural feminists because these topics are used to demonstrate - and frequently, to define $e^{45}$-women's oppression by men, and because they allow American women to assert the universality of women's experience. ${ }^{46}$ The version of gender essentialism articulated in Coleman's essay, whereby phenomena such as poverty and racism are completely eclipsed by culturally determined sexism as a source of oppression, entirely ignores any context that might differentially shape a woman's experience or agency. 47

Coleman's failure to examine the subject position of non-European immigrant women intersects in disturbing ways with the notions of victimhood, agency, and resistance depicted in her article. Her article suggests that when non-European women are the victims of crimes, they are passive objects, waiting to be saved by the arm of the law and the largesse of European American feminism. ${ }^{48}$ They are devoid of any agency, and there is no sign that they resist patriarchal formations within their com-

43. For example, Mary Daly in the late 1970's asserted that footbinding, sati/suttee, rape, and witchburning demonstrate universalist oppression of women qua women through the ages, through sexualized violence. See Daly, supra note 31 .

44. For analyses of how women of color are marginalized within the discourse of gender essentialism, see Kimberlé Crenshaw, Demarginalizing the Intersection of Race and Sex: A Black Feminist Critique of Antidiscrimination Doctrine, Feminist Theory and Antiracist Politics, 1989 U. Chi. Legal F. 139 [hereinafter Crenshaw, Demarginalizing the Intersection]; Kimberle Crenshaw, Mapping the Margins: Intersectionality, Identity Politics and Violence Against Women of Color, 43 Stan. L. Rev. 1241 (1991) [hereinafter Crenshaw, Mapping the Margins]; Angela P. Harris, Race and Essentialism in Feminist Legal Theory, 42 Stan. L. Rev. 581 (1990); Marlee Kline, Race, Racism and Feminist Legal Theory, 12 Harv. Women's L.J. 115 (1989); Celina Romany, Ain't I a Feminist? 4 Yale J.L. \& Feminism 23 (1991); Leti Volpp, (Mis)Identifying Culture: Asian Women and the "Cultural Defense," 17 Harv. Women's L.J. 57 (1994).

45. See Inderpal Grewal, Dilemmas of Transnational Feminist Practice: Race, Gender, and Nation in "America," in Multicultural Feminism, supra note 33 (manuscript at 22, on file with the Columbia Law Review).

46. See, e.g., Catharine A. MacKinnon, Feminism Unmodified: Discourses on Life and Law 85 (1987).

47. Angela Harris explains why essentialism, while failing to accurately represent the complexities of multiple forms of subordination, is nonetheless appealing:

[A]s a matter of intellectual convenience, essentialism is easy .... [E]ssentialism means not having to do as much work, not having to try and learn about the lives of black [or immigrant] women, with all the risks and discomfort that that effort entails. Essentialism is also intellectually easy because the dominant culture is essentialist-because it is difficult to find materials on the lives of black women, because there is as yet no academic infrastructure of work by and/or about black women or black feminist theory.

Harris, supra note 44, at 605 (footnotes omitted). But, as Marlee Kline notes, "[t]his fear of complexity is a poor excuse . . . for failing to develop more complete and realistic understandings of women's oppression." Kline, supra note 44, at 145.

48. See, e.g., Coleman, supra note 2, at 1160 (If culture is incorporated into the law, "[t]he victims simply are left dead, beaten, raped, and mutilated, and potential victims may 
munities and in the dominant community. But when non-European women commit crimes, they become agents engaged in brutality and deception, and defenders of their culture's patriarchy. ${ }^{49}$ This binary opposition-victim or criminal-emerges from the article's embrace of victims' rights. A more nuanced and contextualized understanding of the positioning of women of color and immigrant women would place their actions within a complex of multiple and fractured social forces, and not deny their full humanity.

Coleman recognizes that immigrant women are not only criminal victims of male immigrant defendants, but also can be defendants themselves in the context of parent-child suicide cases. In an effort to lay claim to a coherent, "objective" position on the use of cultural evidence, free from the "ad hoc fashion [of decisionmaking], based on political or professional affiliations" 50 that she accuses others of following, she twists her reading of these cases in two very different directions. First, her argument reads parent-child suicide through the lens of patriarchal culture, stating that it results from "a subordinating patriarchal custom" that causes a woman to feel "shame" about her husband's infidelity, ${ }^{51}$ which she must purge through suicide, the "culturally appropriate response." 52 This allows Coleman to assert that she feels some sympathy for a woman who tries to commit parent-child suicide, and that she even can conceptualize her to be "a victim." 53 Coleman, however, then abruptly changes course to analogize parent-child suicide cases to the case of Susan Smith: someone who did not actually attempt to kill herself, and who, after killing her children, alleged that her children had been kidnapped by an African American man. ${ }^{54}$

be convinced that the United States is not a place where they can hope to be protected from discriminatory culture-based crimes.").

49. See infra text accompanying notes 54-60 (discussing Coleman's analogy between the parent-child suicide cases and the Susan Smith case); see also Coleman, supra note 2, at 1142 ("If the Kimura case [a parent-child suicide case] is divorced from its cultural context, what is left is a woman who was so despondent about her personal circumstances that she wanted to die, but not without her children. Having this in mind, she carefully planned their deaths (and hers) by drowning.").

50. Coleman, supra note 2 , at 1097.

51. Id. at 1124 n.163.

52. Id. at 1109 .

53. Id. at 1124 n.163.

54. Coleman contends, "the similarities between the two cases [the Susan Smith case and the Kimura case, a parent-child suicide case,] are quite remarkable." Id. at 1142 n.236. Coleman asserts:

Apart from the doctrinally inconsequential fact that Susan Smith drowned her two children by sending a car into lake water in South Carolina, rather than by holding them physically under ocean water in California, the facts of the Smith case were, in all relevant aspects other than culture, the same as those in Kimura.

Id. at 1142. Yet she also writes:

Kimura also is quite a bit more sympathetic than Susan Smith who, as far as we know, was not acting under the influence of a culturally-dictated patriarchal 
The analogy between parent-child suicide and Susan Smith relies on two disturbing assumptions. First, to support the analogy to Susan Smith, Coleman disingenuously defines parent-child suicide cases as instances in which "the mother, after killing her children, is either unsuccessful in her effort to kill herself, or she decides not to take her own life after all." 55 However, Coleman does not (and cannot) cite a single parent-child suicide case where the woman "decides not to take her own life after all," because the very definition of parent-child suicide includes the parent's attempt at suicide. Further, the analogy ignores any racial difference between Susan Smith and the immigrant women she describes, and the way racial positions intersect with both United States and Asian American patriarchies in the parent-child suicide cases. ${ }^{56}$

Why would Coleman's article present such an inconsistent reaction to parent-child suicide cases? The inconsistency appears to stem from a bifurcated presentation of women as exclusively either victims of their culture, or as victimizers of their children. Coleman conceptualizes nonEuropean immigrant culture as solely patriarchal, and thus sees women operating within that framework as "victims," subject to complete cultural determmation; ${ }^{57}$ they act "under the influence of a culturally-dictated pa-

directive, who did not appear to have made any serious effort to kill herself, and who lied intentionally, repeatedly, and very publicly about her role in the killings.

Id. at 1125 n.163 (citation omitted). It appears that Coleman seeks to analogize the parent-child suicide cases to Susan Smith so that she can argue that the children who are the victims of such cases are not as well treated as Susan Smith's children-as demonstrated by a longer criminal sentence for Susan Smith. She also discusses the Nicole Brown Simpson case to show that "European Americans" - as opposed to "non-European immigrants" subjected to "cultural defenses" -are better served by our legal system. Id. at 1138. It is questionable, however, whether the Nicole Brown Simpson case actually demonstrates that "European American women ... are deemed worthy of legal concern." Id.

Furthermore, the Simpson case, wherein racial considerations were pervasive, appears an odd example to choose to cite, given Coleman's contention that our legal system, without explicit "cultural defenses," is somehow color- and culture-blind. For a discussion of the role of race in the Simpson trial, see Cheryl I. Harris, Myths of Race and Gender in the Trials of O.J. Simpson and Susan Smith: Spectacles of Our Times, 35 Washburn L.J. 225 (1996) (examining how the O.J. Simpson and Susan Smith trials reinscribed prevailing ideologies of race and gender).

55. Coleman, supra note 2 , at 1110 .

56. For an illustration of the way in which Asian immigrant women are marginalized through the use of single-axis frameworks which do not address economic, social, cultural, racial, and sexual systems of domination, see Hyun Sook Kim, Theorizing Marginality: Violence Against Korean Women, in Privileging Positions: The Sites of Asian American Studies 217, 227 (Gary Okihiro et al. eds., 1995).

For a sympathetic reading of the way in which Susan Smith may have been affected by social forces, such as childhood sexual abuse, the abdication of male responsibility, and class inequality, see Harris, supra note 54 , at 248-49.

57. On the general notion of cultural determination of Asian Americans, see Volpp, supra note 44, at 94 . The prevalent assumption that Asian Americans are more subject to cultural dictates than any other group in the United States is a major premise of Coleman's piece. 
triarchal directive,"58 and "feel shame" due to a "subordinating patriarchal custom."59 A more sophisticated reading of these cases would posit that parent-child suicide is not the result of women enacting a dictated response to "shame," but rather the result of women experiencing extreme marginalization and abuse; and exercising agency within that context.60 Women are not subsumed by culture, but are in active negotiation with it. Coleman's article does not adopt such a perspective, however, because she chooses to balance interests in favor of legally defined victims. This mandates rejecting a sympathetic understanding of women defendants who might be considered in a political or social sense to be victims. Instead, women who try to commit parent-child suicide are vilified as being "remarkably similar" to Susan Smith, so their interests can be trumped by the interests of their legally-defined victims: their children.

But victimhood is more contingent, and less categorical, than Coleman indicates. As I have argued elsewhere, contextual analyses should be used when considering how culture interacts with the multiple pressures which subordinate individual defendants.61 In contrast, Coleman's definition of victimhood is entirely circumscribed by the law;

Elsewhere, I explain this notion of extreme cultural determination as both the conflation of "culture" with "other," which descends from anthropological and neoimperialist tropes, and the conflation of "Asian" with "foreign," which emerges from the peculiar variant of racism faced by Asian Americans. This cultural determination is dehumanizing because it distances Asian Americans from the understandings of human behavior developed using the Western notions of individualism and psychoanalysis. It is also depoliticizing because it uses culture, and not structural forces such as racism or economic oppression, to explain the existence of problems in Asian American communities. Id.

58. Coleman, supra note 2 , at 1125 n.163.

59. Id.

60. See Volpp, supra note 44 , at $87-95$.

61. See id. at 98 . I will note here that Coleman misrepresents my previous article, (Mis)Identifying Culture, supra note 44, on a number of points. These include her contentions that I argue that cultural evidence should only be admitted for female defendants, and that I would permit use of the "cultural defense" when immigrant men commit crimes against non-immigrant defendants. See Coleman, supra note 2, at 1145-47 \& n.248. Coleman does recognize that I do not actually make either of these statements in (Mis)Identifying Culture, but claims that my argument "effectively leads" to these conclusions. Id. at 1146.

However, my previous article explicitly requests that not every "cultural defense" case be seen as one concerning the subordination of women.

Valuing the principle of antisubordination is more than a game of hierarchical rankings of "who's most oppressed"; it means a serious commitment to evaluating and eradicating all forms of oppression .... The point of antisubordination is not to read every story as a "subordinated woman's story"; rather, it is that one must never explain or close off any story into being just one story. This is exemplified in the Wu case [a parent-child suicide case] since it is also a story about the killing of a child by his parent.

Volpp, supra note 44 , at $98 \&$ n.170 (footnotes omitted). Despite this statement that parent-child suicide should not be understood only as involving women victims, Coleman contends that my previous article fails "to value or even to discuss male victims," Coleman, supra note 2, at 1146, because it "never discusses" the son in the Wu case. Id. at 1146-47. 
only the law can protect victims, who are utterly without agency. Although Coleman asserts that, "[ $t]$ his Article and my views are not part of the conservative 'victims' rights' movement that recently has surfaced," 62 her article is emblematic of victims' rights. Her argument is premised on the notion that all victims are good, and that the law inadequately protects them. ${ }^{63}$ Coleman's thesis privileges the rights of legallydefined victims, even when such privileging requires desperate maneuvering, as exemplified by her characterization of parent-child suicide.

The growth of the victims' rights movement has been spurred by various forces, including campaigns organized to counter sexual assault and domestic violence; the sense that justice is not served by protecting the rights of defendants; and a shift in conceptualizing the purpose of punishment from rehabilitation to retribution.64 We now face a proposed victims' rights amendment to the United States Constitution that would enshrine victims' participation in various aspects of the criminal process as a fundamental right. ${ }^{65}$ Defendants, whose liberty is threatened by the state, are positioned differently in the criminal justice system than victims. "Balancing" the rights of defendants and victims by curtailing the

62. Coleman, supra note 2 , at 1097 n.23. While she declares that she disagrees with the victims' rights movement's focus on retribution, she later complains that: "childvictims of immigrant crime (victims, essentially of cultural pluralism) have been . . . left without protection by the criminal law. This result serves neither the intent of deterrence nor that of retribution." Id. at 1143.

It must also be pointed out here that Coleman's allegation that children are killed because of cultural pluralism is quite breathtaking.

63. For a discussion of the manner in which victim rhetoric is problematic and can harm victims, see Martha Minow, Surviving Victim Talk, 40 UCLA L. Rev. 1411 (1993).

64. See generally Lynne Henderson, The Wrongs of Victim's Rights, 37 Stan. L. Rev. 937 (1985) (discussing the historical evolution of victims' rights and theories of criminal justice in the United States).

65. The proposed amendment, co-sponsored by Senators Diane Feinstein and Jon Kyl, and endorsed by both President Clinton and presidential candidate Bob Dole, states:

Section 1. To ensure that the victim is treated with fairness, dignity, and respect, from the occurrence of a crime of violence and other crimes as may be defined by law pursuant to section 2 of this article, and throughout the criminal, military, and juvenile justice processes, as a matter of fundamental rights to liberty, justice, and due process, the victim shall have the following rights: to be informed of and given the opportunity to be present at every proceeding in which those rights are extended to the accused or convicted offender; to be heard at any proceeding involving sentencing, including the right to object to a previously negotiated plea, or a release from custody; to be informed of any release or escape; and to a speedy trial, a final conclusion free from unreasonable delay, full restitution from the convicted offender, reasonable measures to protect the victim from violence or intimidation by the accused or convicted offender, and notice of the victim's rights.

Section 2. The several States, with respect to a proceeding in a State forum, and the Congress with respect to a proceeding in a United States forum, shall have the power to implement further the rights established in this article by appropriate legislation.

142 Cong. Rec. S3795-S3797 (daily ed. Apr. 22, 1996) (statement of Sen. Kyl). 
rights of defendants, as Coleman's article and the proposed amendment advocate, makes little sense. Balancing, in the context of cases involving cultural defenses, is a jurisprudential tool used more appropriately to make decisions on a case-by-case basis, rather than to endorse universal prescriptions. ${ }^{66}$

The proponents of victims' rights include Justice Scalia, ${ }^{67}$ law and order conservatives, and those who advocate increased protection for victims of gendered violence. Advocating victims' rights from a feminist perspective is not uncommon, but is highly problematic. As Mari Matsuda has written, focusing solely on crimes against women deflects attention from the crimes of the criminal justice system itself-most obviously, its racism. ${ }^{68}$ This racism belies the appropriateness of a prescription which

66. Commentators point out that a trial is not "a sporting event whose rules require 'balance' between defendant and victim." Naftali Bendavid, Victims' Ultimate Revenge, Legal Times (D.C.), July 1, 1996, at 1. See generally Angela P. Harris, The Jurisprudence of Victimhood, 1991 S Sup. Ct. Rev. 77 (our criminal justice system provides rights for criminal defendants in attempt to create orderly alternative to individual retaliation and vigilante justice).

Nonetheless, supporters of the victims' rights amendment seek to equalize the relationship of victim and defendant in the criminal process. As President Clinton recently stated: "When someone is a victim, he or she should be at the center of the criminal justice process, not on the outside looking in .... Amending the Constitution here is simply the only way to guarantee that victims' rights are weighted equally with defendants' rights in every courtroom in America." Remarks Announcing Support for a Constitutional Amendment on Victims Rights, 32 Weekly Comp. Pres. Doc. 1134, 1134, 1136 (June 25, 1996).

Those familiar with the way our criminal justice system works are extremely concerned about expanding victims' rights. Prosecutors, many of whom have used the victims' rights movement for political gain, are among the fiercest opponents of the proposed amendment, for they fear that their ability to make informed, independent decisions will be compromised. For example, they ask, "What if . . a prosecutor wants to accept a plea bargain ... but the victim's relatives ... insist on going to trial?" Bendavid, supra, at 17; see also Henderson, supra note 64 (explaining that proposed victims' rights programs may be undesirable for victims of crimes).

67. In objecting to the Court's holding that a victim impact statement was per se unconstitutional, Justice Scalia noted:

Recent years have seen an outpouring of popular concern for what has come to be known as "victims' rights" - a phrase that describes what its proponents feel is the failure of courts of justice to take into account in their sentencing decisions not only the factors mitigating the defendant's moral guilt, but also the amount of harm he has caused to innocent members of society.

Booth v. Maryland, 482 U.S. 496, 520 (1987) (Scalia, J., dissenting).

68. See Mari Matsuda, Crime and Punishment, Ms., Nov./Dec. 1994, at 86. Matsuda describes the problematic efforts of feminists to use criminal enforcement to combat violence against women. For example, feminists successfully lobbied for passage of the Violence Against Women Act ("VAWA"), even though it included provisions that "vastly increased the number of death penalty offenses and failed to require racial equality in death penalty applications." Id. at 86 . VAWA also has allocated vastly more resources to law enforcement and prosecution than to any other initiatives, such as community education or battered women's shelters. See Fate of Funding for VAWA Tied to the Budget Negotiations, Violence Against Women Activist Update (Nat'l Network to End Domestic Violence, D.C.), Apr. 11, 1996. 
presumes that official excision of "culture" will lead to "culture-blind" and non-racist decisionmaking. ${ }^{69}$ Matsuda also notes that the criminal justice system is predicated on patriarchal structures, and that attempts to strengthen criminal enforcement will not change our culture of violence. ${ }^{70}$ To advocate for "victims' rights" by increasing criminal penalties, without simultaneously critiquing a system that "spawns racism, police brutality, corruption, and a value system of property before people,"71 will not be an ultimately liberatory project.

\section{What Culture? Whose Culture?}

Another premise that underlies Coleman's article is that the culture of non-European immigrants is bound by anthropological constructions such as "rituals," "customs," "native practices" and "traditions." The freezing of non-European culture in such forms as "custom" or "practice" emerges from colonialist and imperialist discourse which opposes tradition (East) and modernity (West), and which associates East with ancient ritual, despotism, and barbarity, and West with progress, democracy, and enlightenment. ${ }^{72}$ This cultural freezing precludes envisioning culture as

69. For a description of the endemic racism that pervades the criminal justice system, see Law Panel Says U.S. is Racist in Applying the Death Penalty, Int'l Herald Trib., July 17, 1996, at 8 (describing finding of International Commission of Jurists that the administration of death sentences in United States is "arbitrary and racially discriminatory"); see also Sheri L. Johnson, Black Innocence and the White Jury, 83 Mich. L. Rev. 1611 (1985) (examining how racial prejudice influences decisionmaking of criminal juries); Holly Maguigan, Cultural Evidence and Male Violence: Are Feminist and Multiculturalist Reformers on a Collision Course in Criminal Courts?, 70 N.Y.U. L. Rev. 36, 45-46 (1995) (describing how criminal justice system reinforces white, traditionally maleidentified values of dominant culture).

Perspectives on the criminal justice system are often affected by stereotypes and their interaction with the way the popular imagination racializes and genders crime. Frequently, individual victims are conceptualized as women, and white; the "victim" -in the form of "the law" that has been broken-is raced as white; and criminals are largely perceived of as men of color. For example, there has been substantial scholarship pointing out the way that rape narratives usually consist of a black rapist and a white victim. See, e.g., Crenshaw, Mapping the Margins, supra note 44, at 1266-82; Jennifer Wriggins, Note, Rape, Racism and the Law, 6 Harv. Women's L.J. 103 (1983).

A recent article indicated that black rapists and white victims are used not only to represent the experience of rape, but to represent the experience of race in America. The New York Times reported recently that a white woman, who had been raped by a black man and had given up her child for adoption, was reunited with that daughter after 33 years of separation. "The mother and daughter reunion has drawn extraordinary attention, with many reporters, and other people outside the family, seeing it as a parable about race and America." Sara Rimer, Across a Barrier, a Family Waited, N.Y. Times, July 7, 1996, at A10. In other words, the black male rapist and white female victim paradigmatically represent race in the United States.

70 . See Matsuda, supra note 68 , at 88 .

71. Id. at 89.

72. See Renato Rosaldo, Culture \& Truth: The Remaking of Social Analysis 41-42 (1993). See generally James Clifford, The Predicament of Culture: Twentieth-Century Ethnography, Literature, and Art (1988) (analyzing Western anthropological accounts of 
encompassing the effect of factors such as the state, economic pressures, or racism; it also prohibits examination of the way that culture is differently experienced and contested within communities. Without such an understanding, representations of culture are limited to being defined by stereotypes.

Culture is not some monolithic, fixed, and static essence. ${ }^{73}$ Coleman recognizes this near the end of her article in what she describes as an "end note,"74 yet she does not integrate this problematization of "culture" into her argnment. Rather, her article consistently reifies notions of culture as stable and compartmentalized. Consider her description of the facts of People $v$. Moua:

From all objective appearances, the woman, who happened to be Hmong, had expressed her wish in some manner to become part of the larger American community-by choosing to work on the campus of Fresno State. However, a knock at her door in the middle of an otherwise normal American working person's day reunited her with Hmong culture in all of its aspects, and united her with a man who embodied it. ${ }^{75}$

Coleman also contends that the woman had decided "to reject the aspects of her parents' culture that are alleged to invite rape."76

Coleman depicts Hmong culture as something that can be shed through becoming "part of the larger American community" and that has no part of "an otherwise normal American working person's day." dichotomization of "Hmong" and "American" polarizes a "we" (normal, American) and a "they" (Hmong) and essentializes the resultant "other" (Hmong). ${ }^{78}$ Such a perspective ignores the inanner in which culture is relational and fluid-namely, that we do not live in "hermetically sealed cultures" that travel with us from cradle to grave. ${ }^{79}$ Her position also

other cultures as contingent fictions); Spivak, supra note 22 (examining relationship of colonialism, feminism and culture).

73. See generally Clifford, supra note 72 (examining fluidity and hybridity of culture); George E. Marcus \& Michael M.J. Fischer, Anthropology as Cultural Critique (1986) (same); Rosaldo, supra note 72 (same); Writing Culture: The Poetics and Politics of Ethnography (James Clifford \& George E. Marcus eds., 1986) (same).

74. See Coleman, supra note 2, at $I 162$ ("the notion that culture is permanent is also fiction"); Id. at I163 ("It is an anthropological fact that almost every culture is being modified, constantly.").

75. Id. at 1150 (discussing People v. Moua, Record of Court Proceedings, No. 3159720 (Super. Ct. Fresno County Feb. 7, 1985)).

76. Id. at 1137.

77. Id. at 1150.

78. See Volpp, supra note 44 , at 71.

79. See Rosaldo, supra note 72, at 44; see also Paul Gilroy, Small Acts: Thoughts on the Politics of Black Cultures 24 (1993). Gilroy is critical of the fact that:

Culture is conceived along ethnically absolute lines, not as something intrinsically

fluid, changing, unstable and dynamic, but as a fixed property of social groups rather than a relational field in which they encounter one another and live out social, historical relationships. When culture is brought into contact with "race" it is transformed into a pseudo-biological property of communal life. 
misses the point that someone like the woman she describes is "American" not only when she works on a college campus, and "Hmong" not only when she interacts with her parents or when she is raped. According to the passage, "American" is equated with progress: the world of work, the college campus, while "Hmong" is associated with barbarity and tradition, in this case, rape. 80 One "happens to be" of a particular ethnicity or race, but one can become American through separating from parents and family and assimilating. In addition to the conflation of Hmong culture with sexual violence, such an understanding of Asian American positionality in the United States relies on extremely contested notions. These include the model minority myth whereby Asian Americans are expected to gain societal acceptance as the "model minority" through work, the idea that immigrants must assimilate into "normalcy," the fusing of immigrant parents with notions of "backwardness" and of "American" children with "progress," and the overemphasis upon intergenerational conflict in defining the Asian American experience. ${ }^{81}$

This freezing and oppositional placement of "Hmong" and "American" is reminiscent of the testimony of Burton Pasternak, the anthropological expert who testified for the defendant in the case People $v$. Chen. Pasternak testified that the difference between "Chinese" and "American" culture would lead a Chinese immigrant man to act more volatilely than an "American" if he believed his wife was having an affair.82 To demonstrate to the court that it would not be unusual for a Chinese immigrant to murder his wife in those circumstances, Pasternak fetishized a supposed difference between "Chinese" and "American," a

Id.

One could argue that this change occurs to the extent that certain cultures are perceived as genetically encoded, for example, with Confucian principles. Along these lines, it has been suggested that we increasingly are seeing what could be called "genetic essentialism": the notion that "personal traits are predictable and permanent, determined at conception, "hard-wired' into the human constitution." Rochelle C. Dreyfuss \& Dorothy Nelkin, The Jurisprudence of Genetics, 45 Vand. L. Rev. 313, 320-21 (1992) (critiquing this trend).

80. Coleman assumes that men who are Hmong are completely determined by barbaric culture-she goes so far as to allege that "a reasonable Laotian Hmong probably would do exactly as the defendant in People v. Moua did." Coleman, supra note 2, at 1123.

81. See Sucheng Chan, Asian Americans: An Interpretive History 167-68, 171 (1991); Neil Gotanda, Asian American Rights and the "Miss Saigon Syndrome," in Asian Americans and the Supreme Court: A Documentary History 1087, 1089 (Hyung-Chan Kim ed., 1992); Lisa Lowe, Heterogeneity, Hybridity, Multiplicity: Marking Asian American Differences, 1 Diaspora 24, 28 (1991); Mari Matsuda, We Will Not be Used, 1 UCLA Asian Am. Pac. Islands L.J. 79, 80 (1993).

82. See Volpp, supra note 44, at 64-77. Pasternak alleged that in China, unlike in the West, casual sex, adultery, and divorce are extreme deviations from social mores, and that a man whose wife was adulterous would be thought to have a kind of "stain" upon him, indicating that he had lost "the most minimal standard of control within his family." Id. at 69 n.55. Pasternak's portrayal was substantiated neither by fact nor by his own testimony. See Id. at 70 (citing Record at 105-08, People v. Dong Lu Chen (N.Y. Sup. Ct. Dec. 2, I988 (No. 87-7774))). 
difference so great that, when asked to define what he meant by "American," he responded by identifying himself, a white male, as the "average American," and by describing American as not "Chinese."83

Coleman's article describes the "culture" of non-Europeans in terms such as "time-honored," "tradition" and "practice," portraying members of a community as behaving solely in accordance with ancestral ritual. ${ }^{84}$ This prohibits the realization that "culture" can encompass information about social context that implicates an individual's relationship to the "dominant" community or the state. Discussions of "culture" are frequently used to preclude consideration of the way the state or dominant community affects what is constructed as "culture." For example, the notion of a "culture of poverty" tends to absolve the government or dominant community from any responsibility for economic devastation in African American communities. The description of the exploitation of immigrant garment workers by immigrant sweatshop owners as "cultural,"85 thereby erasing the complicity of transnational corporations (garment industry manufacturers and retailers) and the state (government agencies), is another exainple. ${ }^{86} \mathrm{~A}$ more expansive vision of what

83. Id. at 70-71 (citing Record at 76).

84. See Coleman, supra note 2 , at 1093 ("time-honored, customary practice of parentchild suicide"); id. at 1094 ("time-honored tradition of female circumcision"); id. at 1106 ("marriage-by-capture ritual"); id. at 1166 (asserting that the cultural defense is irreconcilable with progress "at the core of the broader American culture" because it "permits customary practices such as female genital mutilation, mother-child suicide, marriage-by-capture, and other gender-motivated violence to escape the full sanction of the criminal law").

85. For an example of an article in which sweatshop violations were explained as the result of "culture," see Jane H. Lii, Week in Sweatshop Reveals Grim Conspiracy of the Poor, N.Y. Times, Mar. 12, 1995, at Al (describing exploitation in contract shop and noting "Everyone quotes a Chinese saying: 'The big fish prey on the little fish, the little fish in turn prey on the shrimp, and the shrimp can only eat dirt.' "). For a criticism of this view, see James Ledbetter, The Times: Tryin' to Find Chinatown, Village Voice, Apr. 18, 1995, at 9 ("[S]ome Asian activists told me they thought [Lii's article] reinforced stereotypes by portraying worker exploitation as a Chinese cultural tradition.").

Similarly, some observers describe the phenomenon of sweatshops as immigrant on immigrant violence-the importation of a form of exploitation that normally does not occur in the United States. For example, in an August 1995 raid on an apartment complex in the $\mathrm{El}$ Monte district of Los Angeles, 72 Thai workers were discovered in slave-like conditions sewing garments for some of the largest retailers and manufacturers in the country. Victoria Bradshaw, then Labor Commissioner of the State of California, exclaimed: "I never would have believed a situation like this could exist in the United States." George White, Workers Held in Near-Slavery, Officials Say, Los Angeles Times, Aug. 3, 1995, at Al. Her statement implies the normative notion that this kind of workplace exploitation is expected to exist in other countries, and that the United States is a site of liberation. Laura Ho, Catherine Powell and I have written about the struggle of the El Monte workers to recover from retailers and manufacturers, and how transnational mechanisms can be deployed to enforce workers' rights. See Laura Ho et al., (Dis)Assembling Rights of Women Workers Along the Global Assembly Line: Human Rights and the Garment Industry, 31 Harv. C.R.-C.L. L. Rev. 383, 394-413.

86. Calling sweatshop exploitation "cultural" disregards the role of key players: manufacturers and retailers, which largely control what happens in the garment industry, 
constitutes "culture" can be used in the context of what are asserted as "cultural defenses." Cultural evidence should include information on the ways the state, transnational corporations, and the dominant community affect an immigrant, through such factors as immigration status, the inaccessibility of the local police department, economic constraints, racism and anti-immigrant violence, and the lack of accessible shelters for battered immigrant women.

Coleman's prescription also ignores ${ }^{87}$ the enormously important point that culture is experienced differently by different people within a particular community, for example, along lines of age, gender, class, race, or sexual orientation.88 This understanding is crucial when responding to cases where immigrant men defend violence against women on the basis of culture. Rather than perceiving these cases to be about the progressive "Western" feminist saving the immigrant woman from her patriarchal culture, we should understand them to raise the question of how to dismantle claims of cultural authority housed in specific representations-claims which are contested within communities. While considering cultural evidence when culture is contested, and not a static essence, is

and labor law agencies, charged with enforcing labor standards for all workers. Labor law agencies currently collahorate with the INS due to the prevalent anti-immigrant climate, which results in immigrant workers being deterred from asserting their rights to the minimum wage, overtime pay, safe working conditions, or union representation. See Elizabeth Ruddick, Silencing Undocumented Workers: U.S. Agency Policies Undermine Labor Rights and Standards, 23 Immigr. Newsl., June 1996, at 1 (attributing increasing violations of rights of immigrant workers to cooperation of labor enforcement agencies with the INS). See generally Jennifer Gordon, We Make the Road by Walking: Immigrant Workers, the Workplace Project, and the Struggle for Social Change, 30 Harv. C.R.-C.L. L. Rev. 407 (1995) (describing the problems faced by immigrant workers, and the failure of government agencies, legal services, and unions to confront and solve those problems).

87. Coleman does briefly acknowledge that culture may be contested within communities. Coleman admits:

[T] here is the problem of the existence of the custom or practice-that is, does it exist at all, and if it does, is it culturally acceptable in the minds of all or merely some segments of the foreign society at issue; second, there are difficulties in interpreting the custom or practice-that is, is the custom or practice as the defendant has described it, or are there nuances that he has not described that are relevant to a full understanding of its value for purposes of legal analysis.

Coleman, supra note 2, at 1162-63.

However, Coleman does not engage the complex questions raised by the fact that culture is contested within communities. Rather, she uses this fact to bolster her position that immigrant culture does not belong in the courtroom, on the basis that these complexities raise too many problems for the judicial system. See id.

88. Her article's erasure of any notion of agency or resistance on the part of immigrant women from non-European communities is linked to this failure.

On the way culture is experienced differently within communities, see Rosaldo, supra note 72 , at 19-20. He argues that we should think of culture "as a more porous array of intersections where distinct processes crisscross from within and beyond its borders," where these processes often develop from different identities. See also Volpp, supra note 44 , at 76-77, 84, 93-94 (examining the way discussions of culture and "cultural defenses" frequently erase competing perceptions of culture). 
admittedly a daunting task, trials are designed to sort through the thickets of competing expert evidence, as Holly Maguigan points out. 89

Glossing over the fact that culture is contested within communities allows Coleman's argument to leap from the "cultural defenses" asserted in these cases to general invocations of "culture." ${ }^{\circ 0}$ But why assume that presentations of culture in a handful of criminal cases define the culture of entire communities when it is well known that defendants will use whatever means necessary, including playing on racial and other stereotypes, to explain their actions?

To demonstrate the fallacy of such an assumption, one could look at the case People v. Rhines, ${ }^{91}$ where the defendant, indicted for rape, sought to admit expert testimony that black people tend to speak loudly, and that the victim, who was also black, would not have been intimidated by his loud speech. The assumption would require the conclusion that this representation constitutes "black culture," asserted by all black people regardless of gender, sexuality, or any other of a multiplicity of factors. ${ }^{92}$ The judge in the Rhines case was quick to reject the proffered evidence, calling it "an inexcusable slur on all females of the black race." 93 In contexts where it may not be so obvious that the presentation of evidence replicates crass stereotypes, attorneys should make an effort to involve community members who are sensitive to the dynamics of power and

89. See Maguigan, supra note 69 , at 96 . Maguigan's article is a very thoughtful analysis of the incredible complexities involved in this issue. Not surprisingly, I take issue with Coleman's contention that Maguigan's article "does not seek to address the larger policy question of whether a cultural defense should exist in our laws," presumably "because of Maguigan's practical perspective." Coleman, supra note 2, at 1148.

90. The frequent stereotyping of non-European culture may reflect the way nonEuropean immigrants to the United States and, frequently, their descendants are thought of as unfamiliar and "foreigu." On the perception of Asian Americans, specifically, as foreigu, see, for example, Keith Aoki, "Foreign-ness" and Asian American Identities: Yellowface, World War II Propaganda and Bifurcated Racial Stereotypes, UCLA Asian Pac. Am. L.J. (forthcoming 1996); Robert S. Chang, Toward an Asian American Legal Scholarship: Critical Race Theory, Post-Structuralism, and Narrative Space, 81 Cal. L. Rev. 1241, 1251-65 (1993); Neil Gotanda, "Other Non-Whites" in American Legal History: A Review of Justice at War, 85 Colum. L. Rev. 1186, 1188 (1985).

91. 182 Cal. Rptr. 478 (Cal. Ct. App. 1982).

92. In People v. Rhines, the defendant sought to admit evidence that he had made a reasonable mistake about the consent of a woman who testified that he had raped her by using physical force and an intimidating tone of voice. See id. at 483.

For a critique of the "defense" presented in that case, see Crenshaw, supra note 39, at $402,422$.

\section{The opinion states:}

Defendant's proffered testimony of a black psychologist concerning "the characteristics of black people to speak very loudly to each other" and the purpose for which he sought to use it is on par with his own testimony concerning black women which we consider to be an inexcusable slur on all females of the black race.

Rhines, 182 Cal. Rptr. at 483. 
subordination within particular communities, as I have suggested elsewhere. ${ }^{94}$

\section{III. "BaLkanization"}

Coleman argues that the immigrant women and children who are the legally-defined victims of patriarchal "practices" will be subjected to violations of their right to equal protection if "cultural" evidence is admitted in these cases. ${ }^{95}$ She reaches this conclusion through adhering to a belief in neutral principles, objectivity, and the inherent invidiousness of any consideration of culture or race. Such a vision of the law finds kinship both in legal scholarship prior to the advent of critical schools of legal theory, and in the writing of the more conservative members of the Supreme Court.

In making her equal protection argument, Coleman touts Paul Brest's antidiscrimination principle, ${ }^{96}$ which guarantees "that similar individuals will be dealt with in a similar manner by the government." ${ }^{n 7}$ Her article does not mention that the notion of antidiscrimination has been criticized by numerous scholars who advocate using the construct of antisubordination. In fact, the article claims the "antisubordination principle" to be an "alternative" to the antidiscrimination principle. ${ }^{98}$ But the antidiscrimination principle and the antisubordination principle inform two very different visions of the reach of equal protection doctrine. While both seek to eliminate inequality, the former treats all members of society in a colorblind, or race-neutral fashion, whereas the latter is ex-

94. See Volpp, supra note 44 , at $95-96$.

95. See Coleman, supra note 2, at 1132-36. Presumably, the equal protection argument would go something like this: a victim of crime asserts that she or he was subjected to differential treatment, compared to non-immigrant victims of similar crimes. This differential treatment is manifested by a lesser sentence for the defendant, that results from intentional classification of the victim on the basis of race or national origin by the prosecutor, who decides not to prosecute, or the judge, who decides to admit cultural evidence about the defendant. The differential treatment violates the victim's right to equal protection. As an equal protection claim, this argument appears somewhat unworkable: how would one prove that a prosecutor or judge intended to discriminate against a victim on the basis of race or national origin through considering cultural factors that influenced a defendant? See Randall L. Kennedy, McCleskey v. Kemp: Race, Capital Punishment, and the Supreme Court, 101 Harv. L. Rev. 1388, 1421-40 (1988) (discussing difficulties presented by equal protection claim that asserts rights of black victims to "an equal share of death penalty services"). Kennedy argues that the fact that the death penalty is more frequently meted out to those who murder whites than blacks constitutes a violation of the equal protection of those black victims. His argument, positing an equal protection violation of victims, remedied through limiting the rights of defendants, is distinctly similar to Coleman's proposal, but is not discussed in her article.

96. See Paul Brest, In Defense of the Antidiscrimination Principle, 90 Harv. L. Rev. 1, 1 (1976).

97. Coleman, supra note 2, at 1132 (quoting John E. Nowak \& Ronald D. Rotunda, Constitutional Law 597 (5th ed. 1995)).

98. Id. at 1139 n.221. 
plicitly color conscious, and considers the concrete effects of government policy on people's substantive conditions. ${ }^{99}$

Specifically, the antidiscrimination principle looks only to whether a process was fair, and not at its outcome; looks at a specific act or omission and not its context; treats racism as an individual problem, rather than as a societal one; and privatizes racism, so that remedies are meted out solely on the level of the individual. ${ }^{100}$ As described by Alan Freeman:

[Antidiscrimination's] central tenet . . . is the prohibition of race-dependent decisions that disadvantage members of minority groups, and its principal task has been to select from the maze of human behaviors those particular principles that violate the principle, outlaw the identified practices, and neutralize their specific effects. Antidiscrimination law has thus been ultimately indifferent to the condition of the victim; its demands are satisfied if it can be said that the "violation" has been remedied. ${ }^{101}$

In "(Mis)Identifying Culture," I proposed that antisubordination be a normative value factored into cases involving "cultural defenses." 102 I critiqued the existing legal scholarship, which advocated either admitting cultural evidence in the name of cultural relativism, or excluding it, by invoking the need for immigrants to assimilate (which is Coleman's posi-

99. For critiques of the antidiscrimination principle, see Kimherlé W. Crenshaw, Race, Reform, and Retrenchment: Transformation and Legitimation in Antidiscrimination Law, 101 Harv. L. Rev. 1331, 1334-35; Alan D. Freeman, Legitimizing Racial Discrimination Through Antidiscrimination Law: A Critical Review of Supreme Court Doctrine, 62 Minn. L. Rev. 1049, 1053-54 (1978); Dorothy E. Roberts, Punishing Drug Addicts Who Have Babies: Women of Color, Equality, and the Rights of Privacy, 104 Harv. L. Rev. 1419, 1451 (1991).

100. See Brest, supra note 96 , at 6-12.

101. Freeman, supra note 99 , at 1053-54 (footnote omitted). He characterizes the result of the antidiscrimination principle as follows:

THE LAW: "Black Americans, rejoice! Racial discrimination has now become illegal."

BLACK AMERICANS: "Great, we who have no jobs want them. We who have lousy jobs want better ones. We whose kids go to black schools want to choose integrated schools if we think that would be better for our kids, or want enough money to make our own schools work. We want political power roughly proportionate to our population. And many of us want houses in the suburbs." THE LAW: "You can't bave any of those things. You can't assert your claim against society in general, but only against a named discriminator, and you've got to show that you are an individual victim of that discrimination and that you were intentionally discriminated against. And be sure to demonstrate how that discrimination caused your problem, for any remedy must be coextensive with the violation. Be careful your claim does not impinge on some other cherished American value, like local autonomy of the suburbs, or previously distributed vested rights, or selection on the basis of merit. Most important, do not demand any remedy involving racial balance or proportionality; to recognize such claims would be racist."

Id. at 1049-50 (footnotes omitted).

102. See Volpp, supra note 44, at 63. 
tion). ${ }^{103}$ Instead, I suggested that claims of cultural authority in these cases be approached in a more thoughtful manner, whereby what is presented as "culture" is interrogated for the power dynamics at issue, within a context that recognizes the power dynamics also implicated in mainstream culture and the law. This would mean using the principle of antisubordination to examine and challenge who makes claims to cultural authority in these cases, and what that culture is claimed to be. ${ }^{104}$

In contrast, Coleman relies on the antidiscrimination principle to preclude such a case-by-case basis examination of cultural representation. Rather, in keeping with the antidiscrimination principle's privileging of process over outcome, she seeks a "neutral" process with which to uniformly resolve all cases involving "cultural defenses." She seizes upon the balancing test, which she describes as an "apparently fair and objective tool." 105 She contrasts this fairness with the "political or emotional" methodology that previously has been used to interpret "cultural defense" cases. In other words, she asserts that prior scholarship on the issue has been inadequate and insufficiently "objective."106 Of course, a balancing test is not a neutral "tool," but instead a test that measures and weighs normative values, such as how one regards the interests of coinpeting parties. ${ }^{107}$ Describing a balancing test as "objective" only serves to mask the considerations of raw power at issue. ${ }^{108}$ Further, the stated desire for a "neutral process" is reminiscent of Herbert Wechsler's 1959 condemnation of the Supreme Court in Brown v. Board of Education for

103. Holly Maguigan also has argued that the difficult issues raised by "cultural defenses" require rejecting an all-or-nothing approach that either precludes all cultural evidence, or admits it without challenge. See Maguigan, supra note 69 , at 43 ; Volpp, supra note 44 , at 58-59.

104. Similarly, Holly Maguigan has emphasized the importance of using rebuttal testimony to counter "outmoded, Eurocentric stereotypes." Maguigan, supra note 69, at 94-95 (pointing out that "expert testimony of anthropologists, psychologists, and sociologists can serve to support racist, anti-immigrant, and sexist stereotypes and can invite both acquittals and prejudice against other members of a culture based on those stereotypes," and the importance of rebutting such testimony).

105. Coleman, supra note 2 , at 1156 . While Coleman evinces a recoguition that there have been critiques of the balancing test, she defends its use by reporting that "without question, the doctrine is alive and well in our jurisprudence." Id. at 1156 n.295.

106. Id. at 1156. This claim, which privileges pure procedure and disparages contextualized and specific descriptions as "emotional," falls within what Patricia Williams describes as the promotion of the "existence of transcendent, acontextual, universal legal truths or pure procedures .... The more serious side of this essentialized world view is a worrisome tendency to disparage anything that is nontranscendent (temporal, historical), or cotitextual (socially constructed), or nonuniversal (specific) as 'emotional,' 'literary,' 'personal,' or just Not True." Patricia J. Williams, The Alchemy of Race and Rights 8-9 (1991).

107. See T. Alexander Aleinikoff, Constitutional Law in the Age of Balancing, 96 Yale L.J. 943, 972-1002 (1987).

108. See Id. at 992-1002 (asserting that balancing tests mask substantive considerations). 
striking down racial segregation by using "political" and "substantive" values rather than "neutral principles." 109

The values Coleman seeks to balance are those of immigrant defendants and their victims, which she poses in competition with one another. ${ }^{110}$ She declares that she does not want to privilege the rights of victims over the rights of defendants, even though conservatives and some feminists adopt this position: "When in Rome, do as the Romans do!,' is the conservative cry whenever multiculturalism appears to threaten established institutions in American society ... . Feminists generally do not align themselves with conservatives; however, because our 'Rome' is a better place for women from the Western perspective, they do stand aligned ...."111 Expressing discomfort with a naked advocacy of "victims' rights,"112 Coleman then searches for other "objective" legal tools to use to sort out her prescription. The additional "objective" tools she locates include the allegation that a "less burdensome alternative" already exists for defendants, 113 and an examination of "social utility." In her opinion, any "social utility" furthered by the use of cultural defenses is belied by the fact that allowing such defenses will create "balkanization" and "gender and racial apartheid"-as existed in the past. ${ }^{114}$

Coleman invokes the history of apartheid in America by citing the "black codes" enacted by several Southern states after the Givil War. ${ }^{115}$ This analogy indicates a belief that individual cases of consideration of cultural evidence can be equated with de jure apartheid. ${ }^{116}$ The threat that "culture consciousness" will promote domination- "apartheid"rests on a misperception of non-European culture as more inherently patriarchal than "American" culture, so that "culture consciousness" promotes domination, for example, by serving racist or sexist ends. In order

109. See Herbert Wecbsler, Toward Neutral Principles of Constitutional Law, 73 Harv. L. Rev. 1, 32-35 (1959). For a critique of Wechsler's article, see Cbarles L. Black, Jr., The Lawfulness of the Segregation Decisions, 69 Yale L.J. 421, 421 (1960) (critiquing Wechsler's argument for requiring neutralization of lived historical experiences and shared social meanings); Gary Peller, Neutral Principles in the 1950's, 21 U. Mich. J. L. Reform 561, 618-21 (1988) (critiquing Wechsler's failure to see that promoting procedural neutrality of the Court in deferring to substantive values of the legislature is itself a substantive value choice, and that "neutral process" is contaminated by unequal power distributions and inequality).

110. See Coleman, supra note 2 , at 1157-58.

111. Id. at 1158.

112. Coleman asserts that the "Rome is a better place" perspective does not reflect the "liberals' dilemma," with which she identifies, because it inherently incorporates the judgment that the rights of victims outweigh those of defendants. Id.

113. Id. Coleman's "less burdensome alternative" is to allow defendants to admit cultural evidence at the sentencing phase. For a discussion of this assertion, see infra text accompanying note 186 .

114. Coleman, supra note 2 , at 1098, 1161-62.

115. See id. at 1129-30.

116. In fact, she warns that considering cultural evidence "inevitably would result in the evolution of "culture codes' " which she likens to "slave and black codes and gender discriminatory laws." Id. at 1167. 
to provide a jurisprudential tool with which to ward off this threat, Coleman collapses culture with national origin and race, so that she can link culture to a suspect classification. She then argues that consideration of a non-European immigrant's culture represents illegal classification on the basis of national origin or race. ${ }^{117}$

In her attempt to portray the invidiousness of considering culture, Coleman relies upon doctrine which asserts the necessity of ignoring one's race or national origin, and thus links "cultureblindness" to "colorblindness." She contends: "Because of our history of discrimination, the [antidiscrimination] principle also requires that suspect decisions be closely examined even when-or perhaps particularly when-the intent of the decisionmakers appears or is alleged to be legitimate."118 In other words, because our nation's history is replete with de jure segregation, our legal system is now prohibited from explicitly considering race or national origin, and should be "colorblind." 119 It is unclear why Coleman chooses to stress that benign classifications should be examined particularly closely. Possibly, like Justice O'Connor in Adarand Constructors $v$. $P e n a$, she espouses a belief that it is difficult to differentiate between what Justice Stevens, in his dissent, called a "No Trespassing sign" (invidious discrimination) and a "welcome mat" (benign discrimination). ${ }^{120}$ Alternatively, a condemnation of benign consideration of race or national origin is simply required to make her thesis logically coherent. Because cultural evidence is allowed on the basis of benign classification of a defendant, her article must critique color-conscious decisionmaking on any basis. ${ }^{121}$ Regardless of the rationale, her association of consciousness

\section{See id. at 1133-35.}

118. Id. at 1132 (footnote omitted).

119. While Coleman acknowledges that our current jurisprudence demands classification on the basis of race or national origin to be met with strict scrutiny, she also calls for an actual prohibition of any consideration of race or ethnicity. "Because the government is charged with ensuring the equal protection of the laws, it is required, in the first instance, to ensure that judges and prosecutors do not make decisions that are based on race or ethnicity." Id. at 1134 .

120. $115 \mathrm{~S}$. Ct. 2097, 2120-21 (1995) (requiring federal race-based affirmative action programs to be subject to strict scrutiny). As Justice Stevens writes:

There is no moral or constitutional equivalence between a policy that is designed to perpetuate a caste system and one that seeks to eradicate racial subordination.

...

The consistency that the Court espouses would disregard the difference between a "No Trespassing" sign and a welcome mat. It would treat a Dixiecrat Senator's decision to vote against Thurgood Marshall's confirmation in order to keep African Americans off the Supreme Court as on a par with President Johnson's evaluation of his nominee's race as a positive factor. It would equate a law that made black citizens ineligible for military service with a program aimed at recruiting black soldiers.

Id. at 2121 (Stevens, J., dissenting).

121. It is also possible that Coleman seeks to emphasize the invidiousness of explicit consideration of national origin and race so as to protect the civil rights of whites. There is a suggestion of this in that she describes Adarand not as threatening to end affirmative 
of race or national origin with legal apartheid constitutes part of the neoconservative attack on color-conscious scholarship. ${ }^{122}$

Coleman's position evinces no recognition that colorblind laws can be, and have been, detrimental to people of color, and that colorconscious laws can be, and have been, beneficial. ${ }^{123}$ To call for color- or culture-blindness in the context of sexual violence cases is especially curious, as there is significant scholarship pointing out that women of color cannot be adequately subsumed under prevailing feminist critiques of laws addressing domestic violence and rape. ${ }^{124}$ Such a perspective seeks to forcibly assimilate all difference into a supposed norm, ${ }^{125}$ and ignores the ways that different treatment may be helpful to differently situated communities, as an analysis which uses the principle of antisubordination, rather than antidiscrimination, might indicate. Rather than examining the concrete effects of culture-blind laws on women of color, the article deploys rhetoric exhorting the importance of national uniformity. Seeking to erase all difference in the name of national colorblindness echoes Justice Scalia's stunning conflation of nation and race in Adarand,

action as we know it, but as standing for the proposition that "the government may not discriminate on the basis of race or national origin against any citizens in the provision of its services." Coleman, supra note 2, at 1131 n.191.

122. For other examples of such attacks, see Chen, supra note 4, at 149; Farber \& Sherry, Is the Radical Critique of Merit Anti-Semitic?, supra note 4, at 856.

The attack on race consciousness is being led in the courts not only by Justice O'Connor, but by Justices Scalia and Thomas, who both wrote concurrences in Adarand in order to underscore their conviction that race consciousness is a negative thing. Scalia decried group-based rights in the form of a "creditor or debtor race... [a] concept alien to the Constitution's focus upon the individual," and analogized benign race consciousness with slavery. "To pursue the concept of racial entitlement-even for the most admirable and benign of purposes-is to reinforce and preserve for future mischief the way of thinking that produced race slavery, race privilege and race hatred." Adarand, $115 \mathrm{~S}$. Ct. at 2118 (Scalia, J., concurring). Justice Thomas stated his belief that "government-sponsored racial discrimination based on benign prejudice is just as noxious as discrimination inspired by malicious prejudice," and warned that so-called "benign" discrimination can be as "poisonous and pernicious" as any other form of discrimination. Id. at 2119 (Thomas, J., concurring).

123. For an elaboration of how "colorblindness" has harmed the progress of civil rights, and of the importance of color consciousness, see T. Alexander Aleinikoff, A Case for Race-Consciousness, 91 Colum. L. Rev. 1060, 1073-78 (1991); Crenshaw, supra note 99, at 1341-46; Garrett Epps, Of Constitutional Seances and Color-Blind Ghosts, 72 N.C. L. Rev. 401, 445-48 (1994); Neil Gotanda, A Critique of "Our Constitution is Color Blind," 44 Stan. L. Rev. 1, 2 (1991); Cheryl I. Harris, Whiteness as Property, 106 Harv. L. Rev. 1707, $1766-78,1784-86$ (1993).

124. See, e.g., Crenshaw, Mapping the Margins, supra note 44, at 1245-82 (discussing how the intersection of race and gender makes the experience of domestic violence, rape and remedial reform different for women of color than for white women).

125. See Coleman, supra note 2, at 1160-61 (stating that teaching immigrants "about inconsistencies between their culture and United States law" will only be helpful for immigrants who wish to assimilate and implying that others must be forcibly assimilated through the criminalization of their behavior). 
when he pronounces that: "[i]n the eyes of government, we are just one race here. It is American."126

\section{IV. "West is Best"-Whose Chauvinistic Traditions?}

Coleman's article is premised on the idea that the culture of immigrants from Asia and Africa to the United States lags behind "American" culture, especially in the context of women's "advancement."127 She warns of a "cultural dilemma that pits entrenched citizens of European descent against some immigrants and descendants of immigrants who are not European."128 These non-European immigrants and their descendants, according to Coleman, jeopardize the progress "at the core of the broader American culture,"129 because, in contrast to "American culture," there exists a "chauvinism that is at the core of [non-European] traditions." 130 Coleman suggests that the multiculturalist ideal of equal respect for all cultures must give way when our Constitution, our national culture, and the rule of law are in jeopardy.

\section{A. Cultural Racism}

Coleman's argument is predicated on questionable assertions concerning the relationships among race, culture, and nation. In the not too distant past, purported biological differences were the primary rationale for racial subordination.131 Race was equated with distinct hereditary characteristics, such as differences in intelligence, temperament, and sexuality. ${ }^{132}$ But by the early decades of the 20th century, biologism was losing popularity, and ethnicity theory had gained credence. According to ethnicity theorists such as Gunnar Myrdal, race and culture were both considered determinants of ethnic group identification. Ethnic identification was supposed to disappear over time through assimilation into a unitary national culture. ${ }^{133}$ Predicated on the experiences of European immigrants, ethnicity theory faced challenges in explaining the experiences of African Americans. Nonetheless, proponents such as Myrdal argued that the conflict posed between the "American Creed" of equality

126. Adarand, 115 S. Ct. at 2119 (Scalia, J., concurring).

127. See Coleman, supra note 2, at 1140 ("For just as American law and culture once stood as a barrier to the advancement of American-born women in these areas, so too the patriarchal values brought to our country by some immigrants serve as a barrier to the advancement of women from these cultures." (citations omitted)).

128. Id. at 1121.

129. Id. at 1094 .

130. Id. at 1096 .

131. Of course, our era is not entirely free of evolutionary theories of racial inferiority-witness the popularity of the best-selling book, The Bell Curve. See Richard J. Herrnstein and Charles Murray, The Bell Curve: Intelligence and Class Structure in American Life 317-40, 369-86 (1994) (correlating IQ with racial and social stratification). 132. See Michael Omi \& Howard Winant, Racial Formation in the United States: From the 1960s to the 1990s, at 15 (2d ed. 1994).

133. See id. at 17. 
and the actual experience of black racial inequality could be resolved through black assimilation. ${ }^{134}$ Such assimilation would cure the "pathological" aspects of black culture, contended Myrdal, who claimed that black culture's supposed inferiority and difference from a "unified national culture" explained the fact of black racial subordination. ${ }^{135}$

Frantz Fanon has described this shift from biological to cultural explanations for racial subordmation as a progression from vulgar to cultural racism. ${ }^{136}$ With the latter, the culture of certain communities is posited as either inferior or incompatible with the values of the dominant community. Cultural racism positions non-European immigrants in the United States and Europe, as well as African Americans in the United States, ${ }^{137}$ as living according to cultural dictates that are hopelessly backwards and different. ${ }^{138}$ This purported primitiveness or foreign nature of cultural practices is used to legitimize racial subordination. Exaggerating cultural difference from a supposed mainstream culture allows the notions of race and nation to fuse, so that the culture of certain groups is

134. See id. at 17; Gunnar Myrdal, An American Dilemma: The Negro Problem and Modern Democracy 929 (Transaction Publishers 1996) (1944).

135. See Myrdal, supra note 134 , at $928-30$.

136. See Frantz Fanon, Toward the African Revolution 31-35 (Haakon Chevalier trans., $2 \mathrm{~d}$ ed. 1988).

137. The construct of a "culture of poverty" or "culture of violence" in African American communities can be considered an example of cultural racism. The notion that African Americans are subject to certain cultural practices that foster poverty, violence, and dysfunctionality, is exemplified by the Moynihan Report. See Paula Giddings, When and Where I Enter: The Impact of Black Women on Race and Sex in America 325-35 (1984) (discussing the Moynihan Report and its premise that "dominance" of black women led to "humiliated" black men, welfare dependency and a "tangle of pathology"). This notion has also been popularized by the work of Charles Murray. See Charles Murray, Losing Ground: American Social Policy, 1950-1980, at 145-91 (1984) (arguing that social welfare policies since the 1960s have encouraged self-destructive patterns of behavior among blacks and poor people).

138. Etienne Balibar calls this variant of racism "neo-racism," and suggests that in France "the category of immigration is substituted for the notion of race," where the "dominant theme is not biological heredity but the insurmountability of cultural differences." Etienne Balibar, Is There a 'Neo-racism'? in Race, Nation, Class: Ambiguous Identities 17, 20 21 (Etienne Balibar \& Immanuel Wallerstein eds., Chris Turner trans., 1991). Balibar writes that

the assimilation demanded of [blacks in Britain and France] before they can become "integrated" into the society in which they already live . . . is presented as progress, as an emancipation, a conceding of rights. And behind this situation lie barely reworked variants of the idea that the historical cultures of humanity can be divided into two main groups, the one assumed to be universalistic and progressive, the other supposed irremediably particularistic and primitive.

Id. at 25.

On cultural racism, see also Philomena Essed, Understanding Everyday Racism: An Interdisciplinary Theory (1991) (exploring the structure of racism as revealed by the personal experiences of black women in the United States and the Netherlands); Gilroy, supra note 79, at 24-27 (discussing racism toward black cultures in England, the United States, and the Caribbean); Razack, supra note 1, at 898-99 (remarking how cultural differences are used to explain oppression). 
considered to fall outside the borders of "our society" or "American culture."139

The idea that certain cultures are more "advanced" has been discredited as racist for decades by scholars, who point out that the idea developed in the service of Western global conquest. ${ }^{140}$ Constructing a primitive "other" allowed the "West" to define a contrasting identity as "progressive," which was then used to justify colonialism and imperialism. ${ }^{141}$ The notion of inferior cultural practices is frequently invoked in the context of arguing that certain communities must shed those practices in order to assimilate into our "national culture."

Of great siguificance here is the deployment of these notions of cultural inferiority and inassimilability through the apparatus of the law and the state. Coleman's argument perceives cultural difference as jeopardizing the uniformity of our law and nation: she presumes a uniform, cultureless legal regime facing the threat of difference. But United States law is not devoid of culture. ${ }^{142}$ While Coleman's piece assumes that law and culture are entirely autonomous, and that law can somehow govern and control culture, culture already infuses the law. ${ }^{143}$ Further, the idea of a uniform law and nation is in fact constructed by representing certain communities as marginal, culturally "different," and threatening to the legal order.

Paul Gilroy describes the way the notion of unified national culture has been articulated in Britain around the theme of legality and the constitution, which immigrant defendants are alleged to violate. Gilroy describes the creation of a moral panic about "muggings" by black immigrants in Britain, where black crime has been seen as disrupting the reverence for law, which is conceptualized as a fundamental component of "Englishness." "Black crime" is considered expressive of "black ethnic-

139. See generally Gilroy, supra note 79 , at $63-72$ (discussing relationship between British nationalism and racism).

140. See Edward W. Said, Orientalism (1978) (explaining how the creation of "the Orient" in European discourse and imagination has supported cultural domination); Spivak, supra note 22, at 197-221 (discussing how changes in power structures are signalled when sign-systems change).

Imperialism has been justified by ideology which posits a fundamental distinction between the West and the rest of the world, created through perceived geographical and cultural barriers, as well as by methods used to codify difference among peoples, which chart progress "from primitive to subject races," and finally to "superior or civilized peoples." See Edward W. Said, Culture and Imperialism, 108-09 (1993).

141. See Said, Culture and Imperialism, supra note 140, at 108-09.

142. See Magnigan, supra note 69 , at 53 (pointing out that the argument that it is unfair to allow people of color to use "cultural defenses" "ignores the work of scholars who explain that the standards of the dominant culture operate now as a cultural defense by supporting traditional defenses").

143. In fact, culture exceeds the boundaries of law. See Lisa Lowe, Immigrant Acts: On Asian American Cultural Politics (forthcoming 1996) (manuscript at 24-25, on file with the Columbia Law Review) (suggesting that when the state can neither resolve nor suppress inequality, it erupts in culture). 
ity," and thus crime is identified as an expression of black "culture."144 Similarly, Dwight Greene addresses the way race and lawbreaking were conflated and posed as a threat to the state in the construction of the perceived epidemic of "carjackings" in the early 1990s in the northeast United States. ${ }^{145}$

Coleman's article appears to reflect a similar moral panic ${ }^{146}$ about crimes committed by immigrant defendants in the United States. Her article constructs sexual and parental violence as the sole expression of non-European immigrant culture. ${ }^{147}$ Her thesis posits insurmountable cultural difference, constructed through the cases she describes, to express an immigrant ethnicity which is fundamentally incompatible with the United States Constitution and a "unifying American culture."148

In order to prove that gender-based oppression by immigrants is so disturbing, Coleman's article suggests an "American" culture that is uni-

144. See Paul Gilroy, 'There Ain't No Black in the Union Jack': The Cultural Politics of Race and Nation 72, 76 (1987). Gilroy discusses how adherence to the rule of law "symbolizes the imagined community of the nation ... [and how] conflicts between blacks and the law's agents ... have sometimes been seen as a self-fulling prophecy of hlack externality and alienness." Id. at 74. As Gilroy states:

As culture displaced anxiety about the volume of black settlement, crime came to occupy the place which sexuality, miscegenation and disease had held as the central themes and images in the earlier discourses of "race." Crime, in the form of both street disorder and robbery was gradually identified as an expression of black culture....

Id. at 109.

145. See Dwight L. Greene, Naughty by Nurture: Black Male Joyriding-Is Everything Gonna Be Alright? 4 Colum. J. Gender \& L. 73 (1994). Despite the fact that the occurrence of car thefts actually decreased in the early 1990s, there was a perceived explosive increase in "carjackings." Greene explains the construction of this phenomenon as follows:

Using the common links of cars and stereotypes, the media has created the impression of an epidemic of out-of-control young Black men engaging in auto theft . . . The incidents selected for presentation conform to dominant stereotypes about young Black men, single Black mothers, and White women in need of White male protection against a dangerous (Black) world.

Id. at $75-76$.

146. That there currently exists in the United States a panic about immigration generally, and about crimes committed by immigrants specifically, is beyond dispute. Witness the enactment of myriad anti-immigrant laws, including Proposition 187 in Galifornia (currently enjoined in large part in federal court, see League of United Latin Am. Citizens v. Wilson, 908 F. Supp. 755, 764 (C.D. Cal. 1995)), which requires health care and social service workers and school teachers to notify the INS of any suspected undocumented clients or students, and to deny them services. Proposition 187, $\$ 5-7$, 1994 Cal. Legis. Serv. No. 6, at A-78, A-79 to A-80 (West). Nationally, there is pending legislation in Congress to regulate both "legal" and "illegal" immigration. See S. 1664, 104th Cong. (1996); S. 1665, 104th Cong. (1996); H.R. 2202, 104th Cong. (1995). Recently, the Antiterrorism and Effective Death Penalty Act of 1996, Pub. L. No. 104-132, 110 Stat. 1214, was enacted, which contains numerous provisions that detrimentally impact immigrants, mcluding so-called "criminal aliens."

147. See Coleman, supra note 2 , at 1105-13.

148. Id. at 1094. 
fied ${ }^{149}$ and progressive, ${ }^{150}$ which denies the existence of what we could call the American chauvinistic tradition: a history of gendered violence ${ }^{151}$ and ethnocentrism. ${ }^{152}$ This tactic has been labelled "epistemic violence" -a discursive technique used to demarcate difference and marginalize those who are considered as falling outside a dominant culture, while constructing a mythology of the great and progressive West. ${ }^{153}$ As Avery Gordon and Christopher Newfield point out: "[w]ere there indeed a set of 'core American values' ready to assert unambivalent antiracism and democratic equality against their opposites in American life, we would not be in our fourteenth decade of working toward racial Reconstruction of an America without slavery." 154 Furthermore, the fiction that a uniform national culture exists is emblematic of United States cultural nationalism. Historically, the idea of cultural nationalism has been used to describe the assertion of difference by "minority" groups, a fact which has served to prevent the recognition of intense cultural nationalism on the part of the American mainstream. The presumption that the United States and its fictive unified culture is per se more progressive and more protective of women and children than the culture of Asian and African

149. Gordon and Newfield point out that, in recent years, the "prestige of common culture" has been asserted, "as the primary defensive barrier to the dangers posed by the existence of ethnicity and race. Plurality is increasingly seen as a dangerous thing . . . . Common values, shared principles, core beliefs, national purpose, [and] bringing people together . . are invoked repeatedly against a nameless but standing threat of civil war." Avery F. Gordon \& Christopher Newfield, Mapping Multiculturalism 1, 8-9 (Avery F. Gordon \& Christopher Newfield eds., 1996) [hereinafter Mapping Multiculturalism].

150. See, e.g., Coleman, supra note 2 at 1094 (querying whether "there is and should be a unifying American culture that guides our institutions"); id. at 1166 (concluding that "multiculturalism should not be permitted either intentionally or incidentally to erode the progress we have made as a culture in protecting the rights of minorities, women, and children").

151. "In the United States, violence against women is a problem of staggering proportions: a woman is battered every 15 seconds, one out of every five women will be raped in her lifetime, and almost half of all female homicides will be committed by the victim's male partner." Mallika Dutt, With Liberty \& Justice for All: Women's Human Rights in the United States 25 (1994) (footnotes omitted).

152. Coleman recognizes that ethnocentrism exists when she states that "multiculturalism's twin caveats-that we recognize our natural tendency toward ethnocentrism, and that we tread gently if at all upon that which is at the core of immigrant cultures-are essential to the attainment of" "[r] espect for these newcomers." Coleman, supra note 2, at 1166. However, she then concludes, "[n]evertheless, multiculturalism sbould not be permitted . . . to erode the progress we have made as a culture." Id. Her assertion that United States culture is more progressive than nonEuropean culture in certain respects does not indicate a strong concern for avoiding ethnocentrism.

153. The frontier between those who belong and those who are "other" is erected through what Gayatri Spivak calls "the epistemic violence" of the discourses of the Othervia the ideologies of colonialism and imperialism, depicting the colonized, the exotic, the primitive, the anthropological and the folkloric. See Gayatri C. Spivak, Can the Subaltern Speak? in Marxism and the Interpretation of Culture, supra note 41, at 271, 281.

154. Mapping Multiculturalism, supra note 149, at 7-8. 
immigrants is the most rehearsed United States cultural nationalism: "West is best."

The pressures of the global economy in the United States in the form of economic restructuring, or what could be called structural adjustment at home, ${ }^{155}$ have led to contemporary attacks on immigrants that conflate race, lawbreaking, and immigrant status in significant ways, and to a resurgence of racist nationalism. ${ }^{156}$ No longer embracing the tired poor and the huddled inasses with open arms, the United States is more particular these days about who is welcone. People without lawful immigration status in this country are now constructed as "illegals," meaning that their very essence, their identity in the United States, is demarcated as breaking the law. Even though undocumented immigration status is a mutable characteristic, the notion of being "illegal" is used to fix and permanently mark a class of people. "Illegals," those who transgress the boundaries of both nation and law, are not welcome in the "American family." Today, even immigrants whose group identification is constructed through their "legality"- "legal immigrants"-are under attack.

Witnessing the ever-shrinking pool of those considered "acceptable" in this country, one could say that the category "citizen" is now being accorded something of the privilege historically accorded "whiteness." The marginalization of certain groups of immigrants is largely a product of racialization; while one-half of all undocumented persons are visa overstayers, ${ }^{157}$ the specter of "illegal aliens" deployed in immigrant debates is almost always of people crossing the border from Mexico, or Chinese brought in by "smugglers." 158 As Bill Ong Hing has said, "It's no accident

155. As noted by those attending the 1995 NGO Forum in China:

Controlled by international financial institutions, the World Trade Organization and transnational corporations, the global economy imposes Structural Adjustment Programs on countries in the South and economic restructuring in countries in the North in the name of fiscal health. The result is often increasing debt, poverty, and unemployment. Th[is] result[s in] reductions in social programs and services in the areas of health, education and housing ....

NGO Beijing Declaration: September 14, 1995: Labour-related Excerpts, Asian Lab. Update (Asia Monitoring Resource Ctr., Kowloon, H.K.), Aug.-Oct. 1995, at 19; see also Fran Ansley, Standing Rusty and Rolling Empty: Law, Poverty, and America's Eroding Industrial Base, 81 Geo. L.J. 1757, 1758-84 (1993); Ho et al., supra note 85, at 390-94.

156. On the linking of race and nation in the conceptualization of the "problem" of immigration through the phenomenon of "nativistic racism," see Robert S. Chang, Centering the Immigrant in the Inter/National Imagination, U. Or. L. Rev. (forthcoming 1997) (manuscript at 7-8, on file with Columbia Law Review).

157. See Diane Targovnik, Congressional Debate Shows Scope of Legal Immigration, Houston Chron., Mar. 17, 1996, at IA (more than half of illegal immigrants are visa overstayers).

158. In fact, the largest community of undocumented persons in New York state is Italian, followed by Ecuadoreans, Poles, Irish, and Russian. See Jeff Yang \& Karen Lam, Could it Happen Here?, Village Voice, Dec. 6, 1994, at 14.

For a discussion of the "spectacularity" of the "smuggled Chinese," see Colleen Lye, Toward an Asian (American) Cultural Studies: Postmodernism and the "Peril of Yellow 
that the Statue of Liberty faces Europe and has her back to Asia and Latin America."159

This racialization is facilitated by the conflation of nation with family. As Etienne Balibar points out, the fact that nationalism is premised on the identification of a "national community" with a symbolic kinship facilitates contemporary attacks on immigrants. ${ }^{160}$ While people no longer appear to believe that "Middle Eastern terrorists" parked a bomb-laden U-Haul outside the Murrah Federal Building in Oklahoma City, the recently enacted Antiterrorism and Effective Death Penalty Act, signed by President Clinton on the one year anniversary of the Oklahoma City bombing, nonetheless contains myriad provisions aimed at attacking immigrants, and the figure of the "messianic" "Islamic fundamentalist" was used to urge passage of the bill. ${ }^{161}$ We see this identification of nation

Capital and Labor," in Privileging Positions: The Sites of Asian American Studies, supra note 56 , at 47,52 .

159. William R. Tamayo, When the "Coloreds" Are Neither Black nor Citizens: The United States Civil Rights Movement and Global Migration, 2 Asian L.J. 1, 2 (1995) (quoting Bill Ong Hing).

160. See Balibar, supra note 138 , at $100-05$.

161. The Antiterrorism and Effective Death Penalty Act of 1996, Pub. L. No. 104-132, 110 Stat. 1214 ("AEDPA"), contains provisions purporting to eliminate suspension of deportation for individuals who entered the United States without inspection, allow summary exclusion of individuals who arrive at points of entry (including applicants for political asylum), and eliminate judicial review over deportation hearings and discretionary relief from deportation for certain "criminal aliens." For a discussion of the deleterious effects of AEDPA on immigrants, see Lena Williams, A Law Aimed at Terrorists Hits Legal Immigrants, N.Y. Times, July 17, 1996, at A1. President Clinton specifically noted in his signing statement of AEDPA:

This bill also makes a number of major, ill-advised changes in our immigration laws having nothing to do with fighting terrorism. These provisions eliminate most remedial relief for long-term legal residents and restrict a key protection for battered spouses and children. The provisions will produce extraordinary administrative burdens on the Immigration and Naturalization Service. The Administration will urge the Congress to correct them in the pending immigration reform legislation.

Statement on Signing the Antiterrorism and Effective Death Penalty Act of 1996, 32 Weekly Comp. Pres. Doc. 719, 721 (Apr. 24, 1996).

Various members of Congress deployed the image of Islamic terrorists who immigrate into the United States to urge passage of the bill. For example, Representative McCollum of Florida stated:

Mr. Chairman, Islamic fundamentalists are good people, by and large, but there is a radical group of them that control a country called Iran and control a country called Sudan who have a vision of the world that is quite different from ours. They have a vision of controlling with their movement a Messianic totalitarian movement, a southern Europe, the Middle East, northern Africa, the Near East, all the way through India, and over to much of where the Philippines is today, through Southeast Asia, because they believe it is their destiny to do that. They do not think the same way that we do about matters . . . They are, therefore, going to continue to try to bring terrorism into the United States. And that is why this legislation is so darned important.

142 Cong. Rec. H2143 (daily ed. Mar. 13, 1996) (statement of Rep. McCollum). 
and family in the reaction to the Oklahoma City bombing: the New York Tines editorialized that there was "sickening evidence that the enemy was not some foreign power, but one within ourselves." 162

The nation, constructed through the notion of a unified national culture, is what Benedict Anderson calls an "imagined community," where, despite the actual inequality and exploitation that may prevail, the nation is conceived as a deep, horizontal comradeship. ${ }^{163}$ Coleman's article depicts a society where racisin is only a bogeyman of the past, where progress and democracy prevail, where difference exists only outside the law in the form of diverse cultures, and where the neutral application of the law can sustain justice and equality. But the law is not neutral, and principles of abstract equality do not guarantee justice, as legal scholars have pointed out for decades. ${ }^{164}$

\section{B. Misidentifying Multiculturalism}

The perceived threats posed by immigrants-taking jobs, breaking the law, going on welfare and threatening national culture-present challenges for those who feel the need to urge assimilation. This is the currently popular backdrop against which Coleinan presents her simplistic caricature of multiculturalism. ${ }^{165}$ This version of multiculturalism

162. Linda Greenhouse, Exposed: Again, Bombs in the Land of the Free, N.Y. Times, Apr. 23, 1995, § 4, at 1 .

163. See Benedict Anderson, Imagined Communities 7 (rev. ed. 1991). Anderson writes that the nation is "an imagined political community" that is "imagined as both inherently limited and sovereign." The nation is imagined as a community because, regardless of the actual inequality and exploitation that may exist, the nation is conceived as a comradeship, as a fraternity, that has made "it possible, over the past two centuries, for so many millions of people, not so much to kill, as willingly to die for such limited imaginings." Id. at 6-7.

164. See, for example, the critiques made by legal realism, Critical Legal Studies, feminist legal theory, and Critical Race Theory. For an extremely short list of examples of these writings, see, for example, At the Boundaries of Law: Feminism and Legal Theory (Martha A Fineman \& Nancy S. Thomadsen eds., 1991) (feminist legal theory); Critical Race Theory: The Key Writings That Formed the Movement (Kimberle Crenshaw et al. eds., 1995) (Critical Race Theory); The Politics of Law: A Progressive Critique (David Kairys ed., rev. ed., 1990) (Critical Legal Studies); Felix S. Cohen, Transcendental Nonsense and the Functional Approach, 35 Colum. L. Rev. 809 (1935) (legal realism); Morris R. Cohen, Property and Sovereignty, 13 Cornell L. Q. 8 (1928) (same); Robert L. Hale, Bargaining, Duress, and Economic Liberty, 43 Colum. L. Rev. 603 (1943) (same).

165. Coleman relies on Stanley Fish to identify two "schools" of multiculturalism: "strong" and "boutique." According to Coleman's article, strong multiculturalists believe that all cultures are of equal value and that no one culture is better than others. Boutique multiculturalists may appreciate or enjoy other cultures but "stop short of approving other cultures at a point where some value at their center generates an act that offends against the canons of civilized decency as they have been either declared or assumed." Coleman, supra note 2, at 1119-20 (quoting Stanley Fish, Boutique Multiculturalism or Why Liberals Are Incapable of Thinking About Hate Speech 1 (unpublished manuscript)).

Coleman could identify her position to be that of a "boutique multiculturalist," whose canon of "civilized decency" is offended by the cultures of Asian and African immigrants. But this would destroy her construction of the "liberals' dilemma," in which 
would require the acceptance of the bizarre customs and behaviors of non-white peoples, at the expense of various long-cherished "American" principles, in the name of equal respect for all communities. ${ }^{166}$ Such a characterization of multiculturalism, that minority culture is pitted against the mainstream in "Culture Wars," 167 is favored by conservatives, and charges that advocates of multiculturalism threaten such notions as "progress," "democracy," and "civilization."

Coleman's article demonstrates no awareness that the meaning of multiculturalism has been the subject of enormous debate. ${ }^{168}$ Among the most commonly expressed conflicts about multiculturalism are: whether multiculturalism is anti-racist or in fact oblivious to racism; whether multiculturalism means cultural autonomy or revisiting a common culture; whether multiculturalism is grounded in grassroots alliances or diversity management; and whether multiculturalism links poli-

multiculturalism and women's rights are posed as antithetical goals. Instead, after acknowledging that there are differing versions of multiculturalism, Coleman goes on to use a caricature of "strong multiculturalism" to characterize multiculturalism in the remainder of her article. With this erasure of differing versions of multiculturalism, her article can charge that multiculturalism per se is in tension with women's rights and must be rejected.

166. For example, Coleman relies on the definition of multiculturalism given by Cathy Young, a self-described "feminist libertarian-conservative" and Heritage Foundation lecturer. See id. at 1120 n.145; Cathy Young, Economy and the Family are the Same Subject: Mrs. Quayle as Feminist, N.Y. Times, Sept. 14, 1992, at A18; Cathy Young, Feminism and Multiculturalism: An Uncomfortable Coexistence, Phila. Inquirer, Apr. 2, 1992 , at A21 ("The central premise of the multiculturalist credo . . . is that all cultures are created equal. To judge other cultures by Western standards is unforgivably ethnocentric.").

167. The notion that "minority" culture threatens the national culture is also deployed in the context of gay and lesbian rights. Justice Scalia, in his dissent in Romer $v$. Evans, which held that Colorado's Amendment 2 violates the Equal Protection Clause, explained homophobic discrimination as simply reflecting "Culture Wars":

The Court has mistaken a Kulturkampf for a fit of spite. The constitutional amendment before us here is not the manifestation of a "bare ... desire to harm' " homosexuals . . . but is rather a modest attempt by seemingly tolerant Coloradans to preserve traditional sexual mores against the efforts of a politically powerful minority to revise those mores through use of the laws.

Romer v. Evans, 116 S. Ct. 1620, 1629 (1996) (Scalia, J., dissenting).

For an examination of the deployment of the notion of "culture wars," see Micaela di Leonardo, Patterns of Culture Wars: The Right's Attack on "Cultural Relativism" as Synecdoche for All that Ails Us, Nation, Apr. 8, 1996, at 25.

168. See, e.g., Williams, supra note 106; Patricia J. Williams, The Rooster's Egg (1995); David Theo Goldberg, Introduction: Multicultural Conditions, in Multiculturalism: A Critical Reader 1 (David Theo Goldberg ed., 1994); Jurgen Habermas, Struggles for Recognition in the Democratic Constitutional State, in Multiculturalism: Examining the Politics of Recognition 107 (Amy Gutmann ed., 1994); Charles Taylor, The Politics of Recognition, in Multiculturalism: A Critical Reader, supra, at 75; Mapping Multiculturalism, supra note 149. 
tics and culture or separates them. ${ }^{169}$ None of this is unpacked in Coleman's simplistic equation of multiculturalism with the favored backlash term, "balkanization."

In adopting the neoconservative version of multiculturalism, Coleman's article can be grouped with what Stanley Fish has called "bad company." 171 Her fear of "balkanization," if courts recognize the "discriminatory, violent customs" 172 of non-European immigrants, bears great similarity to the pronouncements of Arthur Schlesinger which have been critiqued by Fish and others. ${ }^{173}$ According to Schlesinger, our cul-

169. Avery Gordon and Christopher Newfield propose these as heuristic questions that obviously are not as binary in real life, but that reflect the profound ambivalence which surrounds these issues. See Mapping Multiculturalism, supra note 149, at 3-7.

170. Coleman's unfamiliarity with the terminology she uses is also demonstrated by her strange and inaccurate depiction of the term "postmodernism": she alleges that postmodernism "lies at the intersection" of individualized justice and multiculturalism; that Critical Legal Studies, Critical Race Theory, and Feminist Legal Theory are "postmodernist schools"; that there is a "postmodern concept of voice"; that postmodernists advocate that law reflect the diverse voices of all members of society; and that postmodernist theory demands that moral culpability is to be evaluated according to "multicultural" standards. See Coleman, supra note 2, at 1118-19, 1121 n.150.

It appears Coleman has conflated postmodernist theory with her vision of multiculturalism. But multiculturalism descends from an entirely different genealogy (cultural feminism, Third World studies, and ethnic studies) than postmodernism. See generally Feminism/Postmodernism, supra note 41 (exploring relationship between feminism and postmodernism); Feminists Theorize the Political (Judith Butler and Joan W. Scott eds., 1992) (examining relationship between feminism and poststructuralism). While it may appear odd to spend time critiquing postmodernism for what it is not, attacking postmodernism for its presumed characteristics is typical of backlash politics.

171. Stanley Fish, There's No Such Thing as Free Speech and It's a Good Thing, Too 80-88 (1994) (critiquing Arthur Schlesinger's The Disuniting of America for its similarity to racist tracts, which he calls "bad company"). Fish compares Schlesinger's arguments with a series of essays and books written between 1870 and 1925 that warn of the detrimental effects on the pure West of inferior races (identified then not only as non-European but non-Anglo-Saxon, since Anglo-Saxon was defined as the "purest" race) and notes that, in both the smallest detail and the deepest assumptions, these arguments are the same. Id. at 81-87.

172. Coleman, supra note 2 , at 1155 .

173. See Fish, supra note 171, at 80-88; Richard Delgado, Rodrigo's Tenth Chronicle: Merit and Affirmative Action, 83 Geo. L.J. 1711, 1742-44 (1995).

Coleman's position on the difficulty of assimilating immigrant cultures unfortunately finds some kinship in the pronouncements of right-wing demagogues such as Pat Buchanan, Arianna Huffington and Peter Brimelow. Buchanan famously advocated favoring admission for "Englishmen" - in contrast to "Zulus" - stating: "I think God made all people good. But if we had to take a million immigrants in, say, Zulus next year, or Englishmen, and put them in Virginia, what group would be easier to assimilate and would cause less problems for the people of Virginia?" Maureen Dowd, Buchanan's Alternative: Not Kinder or Gentler, N.Y. Times, Jan. 15, 1992, at Al6.

Huffington alleges that "[m]ulti-culturalism shatters the ideal of one nation under God into a secular set of warring tribes and competing ethnic claims," and contends that bilingual programs "are ripping America apart" All Things Considered: Immigrant Supports English Only Movement (NPR radio broadcast, Apr. 25, 1996) (transcript available in Lexis, News Library, Script File); see also Huffington, Values vs. Origins of 
ture is based on Anglo-Saxon tradition-the "unique source" of ideas of "individual liberty, political democracy, the rule of law, human rights, and cultural freedom." $174 \mathrm{He}$ argues that multiculturalism threatens this national culture, and that it is absurd to accord "collectivist," "tribal" cultures dignity and respect equal to that accorded our Western AngloSaxon tradition. ${ }^{175}$

Both Coleman and Schlesinger describe this threat as unique in our nation's history. ${ }^{176}$ Schlesinger calls multiculturalism an "unprecedented ... protest against the Anglocentric culture."177 Coleman contends that: "For the first time in our nation's history, the United States is faced with a cultural dilemma that pits entrenched citizens of European descent against some immigrants and descendants of immigrants who are not European." 178 As Stanley Fish points out, the claim that such perceived con-

Newcomers, Wash. Times, June 16, 1995, at A19 (condemning multiculturalism for harming hoth immigrants and nation); A.M. Rosenthal, Arianna, Go Homel, N.Y. Times, June 20, 1995, at A15 (criticizing anti-immigrant sentiments of immigrant Arianna Huffington).

Brimelow warns of the devastating consequences-cultural and otherwise-of "overwhelmingly visible minorities from the Third World," since "the American nation has always had a specific ethnic core. And that core has been white." Peter Brimelow, Alien Nation: Common Sense About America's Immigration Disaster 10, 19 (1995). Brimelow argues that white Americans "have a right to insist" that the ethnic composition of the American nation be shifted to what it was before the 1965 Immigration Act, which was nearly $90 \%$ white. He seeks to limit immigration to Europeans who share the same "cultural values" as the "American nation." For a critique of racism in Alien Nation see Frank H. Wu, Changing America: Three Arguments About Asian Americans and the Law, 45 Am. U. L. Rev. 811, 816-18 (1996); Ira Glasser, When Charge is Racism in Immigration Reform, N.Y. Times, June 16, 1995, at A26.

174. See Fish, supra note 171 , at $80-81$.

175. See id. at 81 .

176. Coleman, supra note 2, at 1120-21. Coleman charges that "contemporary debate" about multiculturalism "is largely the result of the relatively rapid expansion of non-european [sic] immigrant communities across the country, a phenomenon that began in 1965 with the passage of federal immigration laws which altered the historic preference for European immigrants."

One could point out that ascribing the debates about multiculturalism to the "rapid expansion" of non-European immigrant communities erases the role of African Americans in raising many of the issues discussed under the rubric of multiculturalism.

177. Schlesinger, supra note 10 , at 17 .

178. Coleman, supra note 2 , at $1120-21$. Coleman declares, "[t]he appropriate scope of [the] influence [of non-European immigrants and their descendants] over American institutions is at the core of the debate over multiculturalism." Id. at 1121. She warns that these immigrants are beginning to exercise such influence: "[b]y virtue of sheer numbers, if not political clout, non-European immigrants have begun to force their voice upon the national discourse." Id. at 1120 n.149. The non-European immigrants with whom Coleman is primarily concerned are Asian: three of her four examples where "cultural defenses" have been raised involve Asian immigrants, and her fourth example, of FGS, appears gratuitous. See discussion supra notes 26-33 and accompanying text. The notion that the small percentage of people living in the United States who are Asian Americans have managed to "force their voice" on the national discourse and not experienced consistent marginalization is, of course, belied by reality. See generally Robert Chang, DisOriented: Asian Americans, Law and the Nation-State (forthcoming 1997); Bill Ong Hing, 
flict is new is simply inaccurate, and the perception of the threat itself is premised upon racist ideology. ${ }^{179}$ While Coleman does not explicitly racialize the core values she upholds, her unquestioning reification of racist notions of immigrants, and her argument that non-European immigrants threaten our "unifying American culture" furthers anti-immigrant racism. ${ }^{180}$

\section{Talking Culture}

In an article that addresses the difficult nuances of "talking culture" in the context of sexual violence against women of color, Sherene Razack argues that, in the face of racism, it sometimes has made sense for feminists not to talk about culture at all. This is because of the prevalence of the view that violence in immigrant.communities is somehow a cultural attribute. Culture in immigrant communities is defined through male domination, while in the progressive "West," male domination is considered to be largely a thing of the past. Razack says:

Culture talk is clearly a double-edged sword. It packages difference as inferiority and obscures gender-based domination within communities, yet cultural considerations are important for contextualizing oppressed groups' claims for justice, for improving their access to services, and for requiring dominant groups to examine the invisible cultural advantages they enjoy. ${ }^{181}$

It is indeed difficult to talk about culture. Against a backdrop of imperialist discourse, within a framework of antiracism and antisexism, it is a project that requires constant contextualization and mediation. Yet many scholars and activists have built a foundation, engaging in work that both

Making and Remaking Asian America Through Immigration Policy, 1850-1990 (1993); Lowe, supra note 143; Gary Okihiro, Margins and Mainstreams: Asians in American History and Culture (1994); Asian Americans and the Supreme Court: A Documentary History, supra note 81; Sumi K. Cho, Korean Americans vs. African Americans, Conflict and Construction, in Reading Rodney King, Reading Urban Uprising 196 (Robert Gooding-Williams ed., 1993).

The overestimation of the population of people of color in the United States is pervasive. A recent poll of white Americans indicated that many tend to overestimate greatly the number of people of color in the United States. See Priscilla Labovitz, Immigration-Just the Facts, N.Y. Times, Mar. 25, 1996, at A5 (comparing percentage of United States population thought to be Hispanic (14.7\%) with actual figure (9.5\%); percentage thought to be black (23.8\%) with actual figure $(11.8 \%)$; percentage thought to be Asian (10.8\%) with actual figure (3.1\%); percentage thought to be white $(49.9 \%)$ with actual figure (74\%)). On the American fear of "conquest" by racial others, see generally Robert S. Chang, Reverse Racisml: Affirmative Action, the Family, and the Dream that Is America, 23 Hastings Const. L.Q. (forthcoming 1996).

179. See Fish, supra note 171 , at $82-83$.

180. As Stanley Fish writes, "common values," "national unity," "American character," a "single nation" and the idea of "assimilation" are now "code words and phrases for an agenda that need no longer speak in the accents of the Know Nothing party of the nineteenth century or the Ku Klux Klan of the twentieth." Id. at 87.

181. Razack, supra note 1 , at 896 . 
interrogates the transnational flow of ideas, concepts and actions such as feminism and nationalism, and examines critically how notions of culture are deployed for political ends. ${ }^{182}$

In the specific context of cultural defenses asserted in criminal cases, scholars and practitioners have made various suggestions that develop a process of navigating these complex questions. The difficult issues raised by "cultural defenses" require rejecting an all-or-nothing approach that either precludes all cultural evidence, or admits it without challenge. ${ }^{183}$ Holly Maguigan has argued that endemic racism and sexism in criminal proceedings preclude barring cultural evidence in the manner Coleman proposes, because racism and sexism invariably will shape the perception of a defendant's mental state as unacceptable or incomprehensible. In cases where gendered violence is at issue, Maguigan asks prosecutors to challenge what is presented as cultural evidence, through crossexamination, rebuttal testimony, and reasoned argument. ${ }^{184}$ As stated above, I have proposed that, given the culturally racist tropes that frequently are deployed in these cases, we look at the subject position of who is asserting cultural evidence, and whether the assertion of this evidence reifies stereotypes that further subordination. Information about a defendant's culture should never be reduced to stereotypes about a community, but should concretely address the individual's location in her community, diaspora, and history. ${ }^{185}$ Maguigan and I ask that prosecutors and community groups challenge evidence as irrelevant when it is based on stereotypes with little basis in reality, provide testimony to demonstrate how particular cultural notions are contested within communities, and present evidence that is based on accurate descriptions of

182. For an explication of how feminism can be practiced across cultural and national boundaries, without reifying essentialist notions of "women" or practicing cultural relativism, see Inderpal Grewal \& Caren Kaplan, Transnational Feminist Practices and Questions of Postmodernity, in Scattered Hegemonies: Postmodernity and Transnational Feminist Practices 1, 1-33 (Grewal \& Kaplan eds., 1994).

Two forthcoming articles provide examples of how legal scholarship can address these questions. Madhavi Sunder traces the development of an analysis of sexual harassment in India which, rather than presenting women as helpless victims, focuses on the process of violence. See Madhavi Sunder, In a "Fragile Space": Sexual Harassment and the Construction of Indian Feminism, 18 Law \& Pol'y (forthcoming 1996). Envisioning sexual harassment in this way moves away from gendered essentialism, particularly of women of color as victims of "traditional" cultures, in order to pose sexual harassment as a backlash against women's assertion of nontraditional national identity. Farah Brelvi analyzes a case in which a "cultural defense" asserted for a Muslim Albanian man in Texas was used to conflate supposed national characteristics with supposed religious ones, leading to a media outcry that demonized Muslim parents. Her analysis challenges the unwillingness of the state to overcome the normativity inherent in the "cultural defense." Farah Brelvi, News of the Weird: Specious Normativity and the Problem of the Cultural Defense, 28 Colum. Hum. Rts. L. Rev. (forthcoming Spring 1997).

183. See Magnigan, supra note 69; Volpp, supra note 44.

184. See Magnigan, supra note 69 , at 90-97.

185. See Volpp, supra note 44 , at 100 . 
the pressures that individuals face, both within their communities and without.

In contrast, Coleman would completely excise any discussion of "culture" from criminal cases except at the sentencing phase-in which defendants could present as mitigating evidence information on how their conduct was shaped by their cultural context. This constitutes Coleman's "less burdensome alternative." However, as Maguigan points out, because of the operation of discretion of trial judges in the sentencing phase, limiting consideration of cultural factors to this point risks systematic discrimination against people of color. ${ }^{186}$ Thus, one result of Coleman's proposal could be the very "balkanization" she fears. Coleman also asserts that she would allow an immigrant defendant to make "culture-neutral arguments" like any other defendant-one would hope that she would not preclude immigrants from making the same arguments as non-immigrant defendants! 187 However, she would not allow the admission of any cultural testimony proffered as an "excuse or a reason" for the defendant's acts. ${ }^{188}$ What would this mean for an immigrant woman, charged after attempting to commit parent-child suicide, who sought to admit testimony both as to being battered and as to particular factors specific to her status as a woman of color and as an immigrant? Presumably, Coleman's prescription might allow her to admit evidence on Battered Woman Syndrome, just like any "American" battered woman, but preclude her from presenting other evidence directly relevant to her mental state. ${ }^{189}$ Coleman's scheme could exclude evidence such as how the woman was unable to leave the abusive relationship due to patriarchal structures both within her community, in the form of lack of support, and outside, in the form of police who do not believe her story. Also relevant, but excluded by Coleman's prescription, could be evidence as to the woman's concerns about her immigrant status, an inability to find employment without English skills, and the lack of any language-accessible shelter services. ${ }^{190}$ Exclusion of evidence in the name of saving immi-

186. See Maguigan, supra note 69 , at 69 \& n.116.

187. See Coleman, supra note 2, at 1159 (explaining why "cultural defenses" must be barred by stating: "The criminal law also provides established defenses that in many cases allow the defendant to make culture-neutral arguments that are based on the same facts that would be used to establish the cultural defense.").

188. See Coleman, supra note 2 , at 1160.

189. For a description of the ways in which Battered Woman Syndrome, premised in the cultural feminist privileging of sex differences over any other basis of oppression, has been difficult for battered women of color and gay men and lesbians to access, see Sharon Allard, Rethinking Battered Woman Syndrome: A Black Feminist Perspective, 1 UCLA Women's L.J. 191 (1991); Denise Bricker, Fatal Defense: An Analysis of Battered Woman's Syndrome Expert Testimony for Gay Men and Lesbians Who Kill Abusive Partners, 58 Brook. L. Rev. 1379 (1993).

190. Compare Coleman, supra note 2, with Maguigan, supra note 69 , at 82 (discussing "the uselessness of positing a simple dualistic choice between criminal justice reform aimed at decreasing pluralistic ignorance and reform aimed at incorporating the standpoints of women."). Maguigan illustrates this point by contrasting two cases. In State 
grant women and children from the "chauvinism that is at the core of [their] traditions"191 is not an appropriate or effective response to the difficulties posed by considerations of culture in the courtroom.

One final area in which an examination of the unstated theoretical underpinnings of Coleman's article might prove helpful is her discussion of gender-based asylum. This is a developing area of law which, like the area of "cultural defenses," is raising very difficult questions regarding the intersection of gender, race, nation, culture, and law. Coleman deploys the notion of gender-based asylum in her article in order to pursue a cultural feminist agenda-demonstrating the necessity of saving women from primitive cultures, as contrasted with the progressive culture of the United States. This is another subject that demands a more nuanced understanding of these issues, rather than a reductionist iteration of neoimperialist tropes.

Coleman relies heavily upon the recently issued federal guidelines on gender-based asylum in searching for a sign of a federal policy interest in privileging gender equity over "culture" or "national traditions."192 It is not surprising that Coleman chooses the gender-based asylum guidelines as "proof" that "universal norms" supersede "cultural traditions," because she presents gender-based asylum as resting on the premise that the United States serves as a haven for women subjected to culturally specific norms which are inferior to Western traditions. ${ }^{193}$ But, as scholars

v. Wanrow, 559 P.2d 548 (Wash. 1977) (en banc), Avena Wanrow was convicted of murder after the jury was instructed to consider her actions from an objective, and not subjective standard, and after the judge excluded cultural evidence intended to contextualize her use of violence to protect her family (the conviction was overturned on the basis of an erroneous jury instruction). In the second case, Kathryn Charliaga was acquitted after the judge admitted testimony of experts about both Battered Woman Syndrome and cultural pressures on ber not to leave the relationship. Maguigan, supra note 69 , at 82 (citing Rosanne Pagano, Woman Acquitted After Killing Husband, Anchorage Daily News, Oct. 24, 1991, at A-1; Nell Waage, Expert Testifies Kathy Charliaga Suffered Battered Women's Syndrome, Kodiak Daily Mirror, uct. 17, 1991, at 1).

191. Coleman, supra note 2, at 1096.

192. See Coleman, supra note 2 at 1150-52 (discussing the institution of new INS guidelines in 1995 which permit immigration officers to consider gender-motivated persecution when reviewing a female petitioner's request for asylum). Coleman also seizes upon the Violence Against Women Act (VAWA), which established a new federal civil rights violation for gender-motivated hate crimes, and provided funding for state court training on subjects such as "myths about presence or absence of domestic violence in certain racial, ethnic, religious, or socioeconomic groups," in order to demonstrate the government's concern with eradicating "culturally" based violence against women. Id. at 1151 (quoting 42 U.S.C.A. $\$ 13992$ (1995)). However, such training to dispel the myths about the presence and absence of violence in certain groups would presumably inform courts that wife beating and killing are not solely phenomena in non-European immigrant communities, but are prevalent in dominant American communities as well.

193. She repeats the provisions of the INS Guidelines [hereinafter the Guidelines] which most support her article's vision of women at the mercy of patriarchal cultures:

The Guidelines note specifically that "[t]he laws and customs of some countries contain gender-discriminatory provisions," and that as a result of these laws and customs, "the civil, political, social and economic rights of women are often 
such as Sherene Razack have pointed out, the narratives that emerge from gender-based asylum cases can reify stereotypes about culture and national identity, ${ }^{194}$ just as the narratives that emerge in the context of "cultural defenses" can reify stereotypes: for example, the notions that the United States is a "violence free zone," and that non-European countries are subject to extreme patriarchy. ${ }^{195}$ What is difficult in pointing out this problem is that critiquing the ethnocentric lens through which women refugees are viewed may jeopardize their claim to asylum. If, as Razack suggests, we were to unmask "the trope of pity and compassion" and move towards "a more political understanding of why women flee ... [w] ould this make them too obviously like us"-would such a shift in representation prevent these women from winning gender-based asylum? ${ }^{196}$

diminished." Finally, the Guidelines state that "women who have been raped ... are viewed as having brought shame and dishonor on themselves, their families, and their communities," and that gender-related violence itself is viewed by some cultures "as a failure on the part of the woman to preserve her virginity or marital dignity."

Coleman, supra note 2, at 1152 (quoting U.S. Dep't of Justice, Considerations for Asylum Officers Adjudicating Asylum Claims from Women 9 (May 26, 1995) (on file with the Columbia Law Review)). There are other provisions of the Guidelines, however, that discuss persecution based on criteria such as actual or imputed political opinion. One example discussed in the Guidelines involves a woman (whose family was politically active in El Salvador) who was forced to watch armed attackers murder her family, and was then raped while one attacker chanted political slogans. See the Guidelines at 11 (suggesting that in Campos-Guardado v. INS, 809 F.2d 285, 289 (5th Cir. 1987), the court could reasonably have concluded that the applicant was in fact raped because of her imputed political opinion).

194. Sherene Razack notes that in Canada, women's claims for gender-based asylum have been most likely to succeed when the women are presented as victims of dysfunctional and exceptionally patriarchal cultures and states. This has the following result:

[G] ender persecution, as it is deployed in refugee discourse, . . . requires ... women [to] speak of their realities of sexual violence at the expense of their realities as colonized peoples. It can therefore further First World interests by obscuring Western hegemony and its destructive impact on the Third World. More important, when the histories of imperialism, colonialism, and racism are left out of sexual violence, we are unable to see how these systems of domination produce and maintain violence against women.

Sherene Razack, Domestic Violence as Gender Persecution: Policing the Borders of Nation, Race and Gender, 8 Can. J. Women \& L. 45, 48 (1995).

195. See Kristin Koptiuch, "Cultural Defense" and Criminological Displacements: Gender, Race and (Trans)Nation in the Legal Surveillance of U.S. Diaspora Asians, in Displacement, Diaspora, and Geographies of Identity 215, 227-28 (Smadar Lavie \& Ted Swedenburg eds., 1996); Volpp, supra note 44, at 71-73, 81-83. For a parallel description of how colonialist discourse created "tradition" and obviated the possibility of women's agency in the context of sati, see Lata Mani, Contentious Traditions: The Debate on Sati in Colonial India, in Recasting Women: Essays in Colonial History 88, 91-92 (Kumkum Sangari \& Sudesh Vaid eds., 1989).

196. See Razack, supra note 194 , at 88. 
This is not to call for an end to gender-based asylum, but to suggest that there may be other narratives that can be used to win women asylum that are less likely to reify stereotypes. One possible way to mediate these interests is to focus on the role of the state: its actual sponsorship of gender-based violence, or its failure to provide protection from genderbased violence. This may help evade some of the more pernicious stereotypes about "national traditions" or "cultures" that can result. Another approach, as Sherene Razack suggests, is to ascertain the degree to which an infringement of human rights has restricted a woman's options, including her economic options. ${ }^{197}$ Whatever the specific tactic, what is important here is to be cognizant of the fact that the messages that emerge from particular gender-based asylum, or "cultural defense," cases will be read by the public as fitting into certain master narratives about gender, culture, nation, and race, and to interrogate how more complex and contextualized descriptions can be presented. ${ }^{198}$

We need to abandon the ethnocentric notion of the inferiority of certain cultures, and to understand that all communities are characterized both by patriarchal formations as well as by resistance to those formations. We also must acknowledge that posing multiculturalism as antithetical to feminism is a false opposition and one that is predicated on racism. Further, refusing an explicit consideration of "race" or "culture" within our legal system will not result in "colorblind" and "cultureblind" meritocratic justice, but in a replication of dominant patterns of dispersal

197. See id. at $85-86$.

198. Coleman, unfortunately, never does this. One last example of her limited perspective is her stated desire to assist Asian women "who seek to break [an] oppressive and sometimes violent cultural mold, and who want to become educated, work outside of the home, and have equal rights in other respects." Coleman, supra note 2 , at 1140 . Here Coleman assumes that the "Third World" retains pre-capitalist forms, expressed at the cultural level by traditions which are more oppressive to women, and that only through the entry of women into waged labor does the potential for the liberation of women increase.

Hazel Carby problematizes this notion by asserting that while foot-binding, clitoridectomy, female 'circumcision' and other forms of mutilation of the female body have all been described as 'feudal residues,' existing in economically 'backward' or 'underdeveloped' nations (i.e., not the industrialized West), circumcision of white women in the United States in fact developed with the advent of industrialization. Carby, supra note 24 , at 222.

Of course, Coleman's premise that working outside the home as a wage laborer guarantees women "equal rights" is also faulty. For a description of the endemic workplace violations suffered by women workers in a particular industry, see Ho et al., supra note 85 , at $383-87$.

One could further note that the desire of American feminists to save "Third World" or "immigrant women" from "cultural violence" is unmatched by any similar zeal to liberate women from economic exploitation, presumably because of the unstated complicity of United States-based feminists in global power dynamics and the cultural feminist agenda. See Vasuki Nesiah, Toward a Feminist Internationality: A Critique of U.S. Feminist Legal Scholarship, 16 Harv. Women's Law J. 189, 200-01 (1993) (criticizing focus of United States feminist legal theory on violence and not, for example, on experience of women in export processing zones). 
of power. These are premises that need to be understood if we want to move forward in scholarship examining the relationship of culture and the law. 